Theofanis Exadaktylos and Claudio M. Radaelli (University of Exeter)

JCMS 2009 pp. 1-24 DOI: 10.1111/j.1468-5965.2009.00820.x

\title{
RESEARCH DESIGN IN EUROPEAN STUDIES: THE CASE OF EUROPEANIZATION*
}

\begin{abstract}
$\underline{\text { Abstract }}$
In this article, we contribute to the debate on research design and causal analysis in European integration studies by considering the sub-field of Europeanization. First, we examine the awareness of research design issues in the literature on Europeanization through a review of the debate on causality, concept formation and methods. Second, we analyse how much of the discussion of the trade-offs in causal analysis in mainstream political science has percolated into Europeanization studies. We therefore construct a sample of the Europeanization literature, comparing it to a control group of highly cited articles on European integration. This enables us to control if some patterns are specific to the Europeanization literature or reflect a more general trend in European integration. We then look at trade-offs in the Europeanization sample and in the control group. Our findings indicate that awareness of research design is still low. Europeanization articles differ from the control group in the focus on mechanisms (rather than variables) and the qualitative aspects of time in politics. Complex notions of causality prevail in Europeanization but not in the control group and the cause-of effects approach is preferred to effectsof-causes in the control group but not in Europeanization - in both cases, however, the difference is slight. We conclude by explaining differences and similarities and make proposals for future research.
\end{abstract}

* We would like to acknowledge the support of the Jean Monnet Programme. An earlier version of the article was delivered to the 4th ECPR General Conference in Pisa in September 2007. We would like to thank Susan Banducci, Fabrizio De Francesco, Fabio Franchino, Oliver Fritsch, Simon Hix, Thomas Plümper, Stephen Wilks and two anonymous reviewers for their constructive comments - the usual disclaimer applies. The full set of tables and dataset is available on the Journal's website. 


\section{RESEARCH DESIGN IN EUROPEAN STUDIES: THE CASE OF EUROPEANIZATION}

The academic analysis of European integration set out to investigate dynamics and causes of the integration process, trying to explain the reasons behind the process and the outcomes that it entailed. During the past decade, this field has witnessed the emergence of research questions around the impact of European integration on the domestic level, in terms of policies; the transformation of domestic institutions; and party politics. This is nowadays an almost classic focus for Europeanization studies. But a second strand of the Europeanization literature, often tangential and connected to empirical concerns about measurement and causality, has taken an interest in methods and research design. Specifically, this strand looks at issues in causal analysis. Scholars have discussed concept formation, mechanisms, the interplay between ideational and structural variables, and causal models, particularly the difference between top-down recursive models versus bottom-up research designs. In this paper we contribute to this second strand.

One argument raised in the literature is that Europeanization has potential for the normalization of European integration studies. Put differently, and following Hassenteufel and Surel (2000), Europeanization can be the carrier of less ad-hoc theorizing and more integration with mainstream political science. Thus, does Europeanization provide evidence of awareness of research design debates that are common to 'normal' political science, especially comparative politics? If so, what are the methodological choices made by Europeanization scholars when they encounter classic trade-offs in causal analysis? And finally, is there any original contribution that Europeanization can make to the wider research design debate? These are the three research questions that motivate our paper. 
Up until now, the literature has not done much to answer these questions. To begin with, the difference between Europeanization and European integration is not always clear. Most authors suggest they are connected, and do not explain how empirically one should go about this connection, especially in terms of selecting research design approaches: shall we start from a design on European integration and then zoom on Europeanization? Or look at long periods of time to capture the interplay between the two? Secondly, the reviews available on the subject are concerned with the nature of Europeanization, its mechanisms and outcomes (Börzel \& Risse, 2003; Caporaso, 2007; Lenschow, 2005; Olsen, 2002; Radaelli, 2003). Other studies are more concerned with issues of change in domestic institutions, actors, procedures and paradigms (Börzel, 2005; Bulmer \& Radaelli, 2005; Kassim, 2005; Ladrech, 2005; Lenschow, 2005) or with the impact of the EU on new member states or beyond Europe (Schimmelfennig, 2007; Sedelmeier, 2006). However, they do not address issues of research design. One exception is Graziano and Vink (2007) where issues of methods are explicitly addressed. Methodological discussions, even whey they exist, are not related to the systematic exploration of a sample of the literature this is exactly what we set out to present in this paper. Franchino (2005) provides a useful start for this type of analysis, nonetheless, in this article we move on from his concern with testing theories in European integration articles and look at the nature of causality within a sample of articles on Europeanization.

As mentioned, we take a research design perspective, looking at causal analysis - as defined by Mahoney and Goetz (2006: 228-229). We revisit the debate on causality, concept formation and methods that has emerged somewhat endogenously in the Europeanization literature in the first Section. We present the concept of trade-offs in causal analysis in mainstream political science in the second 
Section. We then build a sample of the Europeanization literature in the third Section and examine how it relates to some fundamental issues in research design, and compare findings with a second control sample drawn from the broader literature on the politics of European integration. The last Section compares and concludes.

$$
* * *
$$

\section{Meta-analysis and systematic reviews}

Whilst Franchino (2005) has looked at content and hypothesis-testing, in this article we focus on method. Meta-analysis is an obvious candidate for this type of analysis. We analyze a sample of Europeanization articles and use a control group of highly cited articles in the more general field of European integration.

We wish to clarify at the outset what we are not doing in this paper. First, we do not examine non-causal approaches. Second, we do not examine the whole literature on Europeanization but only a sample including the most cited pieces. The sample is limited to articles - monographs, edited volumes and individual book chapters are neglected. Third, we do not study a large sample and we have not controlled for the robustness of our results. Finally, we are limiting our analysis to political science research on Europeanization without crossing into other related fields (e.g. environmental studies, industrial relations, socio-legal studies, the sociology of European integration and so on).

Meta-analysis is a form of extracting patterns in the findings of a selected set of studies. Systematic reviews are interrogations of samples of literature with a specific question in mind. According to Lipsey and Wilson (2001), meta-analysis can be understood as a form of survey research in which research reports are surveyed rather than people (Lipsey \& Wilson, 2001: 1-11). Since meta-analysis becomes essentially a survey, it is necessary to develop a coding form or a so-called survey 
protocol. Researchers build up a set of criteria against which the research is appraised. The next step is the creation of the sample of research reports. Each study in the sample is so-to-speak interviewed by a coder (in this case, the authors of this paper), who codes the appropriate information. Finally, the resulting data are analyzed on a statistical basis, to investigate and describe the pattern of findings in the selected set of studies (Lipsey \& Wilson, 2001: 73-88, 146-167). Meta-analysis cannot be performed to summarize theoretical papers, conventional research reviews, policy proposals and other reports of similar nature. We stick to this template, although we do not go beyond basic statistics, given that our samples are small. In essence, our approach is a systematic review informed by the rules (of inclusion and exclusion) of meta-analysis.

\section{Europeanization research: from concepts to research design}

In this Section we look at how Europeanization has encountered issues of research design. This encounter has been triggered by the long debate on definitional issues (Graziano \& Vink, 2007; Olsen, 1995a, 1995b; Radaelli, 2003). In fact, definitions bring in the question of concept formation, and in turn concepts lead to research design decisions about measurement (Radaelli \& Pasquier, 2007).

In this discussion of the concept, Europeanization appears to be a very complex phenomenon in terms of research design. Börzel and Risse (2003) focus on the domestic impact of Europeanization, differentiating three dimensions of analysis of domestic change in terms of policies, politics and polity. Methodologically, they suggest a theoretical framework around the issue of 'goodness of fit' arguing that 'the lower the compatibility between European and domestic processes, policies, and institutions, the higher the adaptational pressure" (Börzel \& Risse, 2003: 61). Research design - they argue - can either be organized around social constructivist 
propositions or test more rational choice arguments. Since empirically there is no neat separation between the logic of appropriateness and the logic of choice, the question remains what should a researcher test exactly, and on the basis of what type of research design? Radaelli (2003) proposes a time-sensitive definition that boils down to the idea that Europeanization is a process, not an outcome. In terms of research design, this invites a choice for process-tracing and Piersonian notions of causality. This definition has also been used to discuss two types of research design, called topdown and bottom-up.

In top-down models (Caporaso, 2007), empirical research starts from the presence of integration, controls the level of fit/misfit of the EU-level policy vis-à-vis the member states, and then explains the presence or absence of domestic change. The model is recursive, i.e. there are no exogenous variables. Technically, this model can be represented by a system of linear equations that are solved simultaneously. It allows for a wide range of intervening variables or mediating factors, as shown by Schmidt (2002). The bottom-up research design exogeneizes the EU level (Radaelli, 2003; Radaelli \& Pasquier, 2007). It starts from the set of actors, ideas, problems, rules, styles and outcomes at the domestic level at time zero - in short, the policy system at a given time. Then it process-traces the system over the years, and identifies the critical junctures or turning points - e.g., when major ideational change takes place, or the constellation of dominant actors is altered. For each juncture, the question becomes: was the cause of this major change domestic, or did the change come from exogenous variables like the EU-level variables or global-level variables? In order to assess the contribution of the variables from outside the domestic system, the researcher goes "up" - from the domestic level to the EU for example and controls the causal patterns. There is a similarity with backward mapping in implementation 
research - a strategy in which we start from the implementation outcome and work causality backwards (Elmore, 1982/1999). Within this discussion on causality and how to draw inferences from empirical evidence, some authors have also made progress in identifying typologies of mechanisms (Knill \& Lehmkuhl, 2002) and outcome (Héritier, Kerwer, Knill, Lehmkuhl, \& Teutsch, 2001). Schmidt (2002) has made a distinction between the mechanisms involving structural variables and the special ways in which discourse has a causal impact on Europeanization and may transform structural variables. She shows how discourse can change preferences, remodel policy problems, and enable or constrain actors, without exercising a direct causal effect on them. To illustrate, discourse can produce change "by altering perceptions of economic vulnerabilities and policy legacies and thereby enhance political institutional capacity to impose or negotiate change" (Schmidt, 2002: 899900). This brings the whole discussion of how to go about research design to a more sophisticated level, as shown by Schmidt's further work on discursive institutionalism (Schmidt, 2006).

Finally, yet another strand of the literature on Europeanization focuses on the complexity of causal chains in the context of temporal sequences connecting major EU policies, like Economic and Monetary Union, to domestic changes Dyson (2000: 646-647; , 2002). Most of Dyson's research is concerned with the problem of prejudging the role of European policies. In his carefully designed collection of case studies on EMU and domestic changes, Dyson and his associates show how previous work on EMU exaggerated the influence of the EU in domestic political change (Dyson, 2002). Recent work by Stolfi (2008) shows how the notion of the EU as external constraint bringing about domestic change has obfuscated the more important role of domestic policy communities. Interestingly, Stolfi uses the bottom-up research 
design to substantiate his theoretical claims, thus connecting the methodological discussion with empirical analysis.

Finally, other authors have entered the debate on research design by using the notion of control group. The question is simple: even if $n$ EU member states are experiencing change, it well may be that k countries outside the EU are also going through the same process of change - for example because they are all part of a global process of diffusion. Saurugger (2005) in her study of interest groups in the EU introduces a test variable studying the activities of such actors outside the European Union. Levi-Faur (2004) in his study of the liberalization of the telecom and electricity industries in the EU measures the net impact of Europeanization as compared to other factors like globalization trends by considering a Latin-American and a rich and developed countries control group.

To conclude, there is awareness of research design issues in Europeanization. This is a sui generis approach to a much wider debate on research design that has occupied mainstream political scientists for quite a while, especially since the publication of the landmark book Designing Social Inquiry by King, Keohane and Verba (1994). It is to this debate that we now turn, in order to select the major tradeoffs in causal analysis to be used in our meta-analysis.

\section{Trade-offs in causal analysis}

In his influential book The Comparative Method (1987), Ragin comments that "social science methodology does not concern mere technique; it concerns the relationship between thinking and researching" (C. Ragin, 1987: 165). For us at least, the issue at stake in causal analysis is not qualitative versus quantitative methods; it is not a matter of black and white answers to research designs problems. We therefore 
follow Brady and Collier's Rethinking Social Inquiry (2004) of causal analysis being a question of trade-offs.

This debate is mostly located in the United States. It has been somewhat neglected in Europe where scholars of political science tend to be focusing more on traditional qualitative research. Yet, the so-called 'pluralistic vision of methodology' (Brady, Collier, \& Seawright, 2006) calls for a merged type of research design that draws from both quantitative and qualitative traditions of social science methods to reach the shared 'overarching goal of producing valid descriptive and causal inferences' (Mahoney \& Goertz, 2006: 228). Nevertheless, the application of methods entails significant trade-offs in causal analysis (Brady \& Collier, 2004). These tradeoffs provide the benchmark for evaluation and criteria-based approaches (Gerring, 2001).

In applying the gist of this discussion to Europeanization, we start from the identification of trade-offs. We then examine trade-offs in a sample of highly-cited articles on Europeanization, and consider a sample of equal size from the wider literature on EU politics as our control group. For the purposes of this paper, the following six categories of trade-offs in causal analysis have been identified. Drawing on the Europeanization sui generis methods debate reviewed in the previous Section, we add a seventh category (top-down versus bottom-up design). As the seventh category is specific to Europeanization, we do not use it for the control group. The six trade-offs are:

(1) 'Cause of effects' versus 'effects of causes' approach;

(2) Concept formation versus measurement;

(3) Complex notions of causation (including multiple-conjunctural causation) versus singular linear causation; 
(4) Omitted variables bias versus multi-collinearity - operationalized for the purposes of the paper as a rich set of independent variables versus parsimony;

(5) Time as a qualitative factor in politics versus time as quantity of years;

(6) Mechanism-oriented research versus variable-oriented

Of course, these criteria are not unique and solid categories, but rather, our amalgamation of the most important issues in a debate with a wide spectrum. Let us explain what they mean.

'Cause of effects' versus 'effects of causes': One of the most important overarching goals of a research design is to produce valid descriptive and causal inferences about significant incidents in the world of political science (Brady \& Collier, 2004: 221). Mahoney and Goertz interpret this trade-off as a manifestation of two different research cultures, qualitative and quantitative. According to these authors, in one case the researcher is looking for the explanation of outcomes in individual cases, in the other case the goal is to 'estimate the average effect of one or more causes across a population of cases' (Mahoney \& Goertz, 2006: 230). We think that there is no reason to assume a stark contrast between qualitative and quantitative cultures - otherwise we might as well have a single trade-off between qualitative and quantitative approaches rather than six. Hence in this paper 'cause of effects' refers to articles that start with a dependent variable in terms of outcomes - for example constrained policy autonomy- and investigate the possible cause, be it global economic interdependence or European integration. 'Effects of causes' is typical of studies that are interested in tracking down how a specific cause, for example European integration, has different effects (for example on domestic politics and policy). 
Concept formation versus measurement: The choice of research design incorporates a second goal regarding descriptive inferences-more specifically regarding their generalization, simplicity and meticulousness in conceptualization and measurement (Brady \& Collier, 2004: 222). Central to this goal lays a critical tradeoff between concept formation and measurement. Simply put, this trade-off opts for either theory testing or theory building. One can of course envisage a sequence from concept formation to measurement in the development of a research field. For the individual researcher, however, the problem is whether to prioritize concept formation or to develop measures. In turns, concept validity, if not adequately addressed, is a major source of measurement error (Mahoney \& Goertz, 2006: 244). Conceptual stretching crops up in the Europeanization literature as well (Radaelli, 2003). Like in the previous trade-off, we do not make the ex-ante assumption that qualitative researchers work on concepts and quantitative researchers privilege measurement. We will see later that indeed there are cases in which quantitative analysis is used to perfect a concept, and cases in which a qualitative study is used to answer a question of measurement, with no sophisticated approach to concept formation.

Complex causation versus singular linear causation: Yet again, in our view this is not a trade-off between qualitative and quantitative research culture. For the purposes of our scoring, we include in complex causation non-linear econometric models, such as structural model equations, multiple conjunctural causation, qualitative comparative analysis, equifinality, increasing returns, punctuated equilibria and models where the causal logic changes before and after a threshold level of a variable (Hall, 2003; Pierson, 2004; C. Ragin, 1987; C. C. Ragin, 2000).

The concept is typically applied to research designs with a small- $N$ sample as it refers to the explanation of a particular outcome rather than the generalization of 
average causal effects. Singular linear causation designs establish which independent variables in a vector $\mathrm{x}=\left[\mathrm{x}_{1}, \mathrm{x}_{2}, \ldots, \mathrm{x}_{\mathrm{n}}\right]$ have a causal impact on the dependent variable.

Omitted variables bias versus multi-collinearity: This is a trade-off between trying to reduce bias generated by neglecting of some important variables and bias arising out of the correlation between independent variables. The more one includes independent variables in the explanation, the higher the likelihood of multicollinearity problems - e.g., two or more explanatory variables are correlated to such a degree that it is impossible to separate their causal effects (King et al., 1994: 119). This issue can be addressed by collecting additional observations to provide more leverage in the differentiation of the causal effects (King et al., 1994: 123). However, according to Brady and Collier (2004: 48), increasing the number of observations "make[s] it harder to achieve other important goals, such as maintaining independence of observations, measurement validity and causal homogeneity." As mentioned, we operationalize this trade-off as one between parsimony (the obvious way to avoid multi-collinearity) and rich explanation (the intuitive way to avoid omitted variables bias).

Time as quantity of years versus time as a qualitative factor: Here what matters is the consideration of time as a factor that can qualitatively affect politics. The reference is to the discussion on temporality in politics (Goetz, 2006; Pierson, 1996, 2004). The trade-off is at the level of initial assumptions. Do we start from hypotheses about slow, complex causal chains of events through time, or from more basic assumptions? The choice is between sophisticated approaches to time that are however difficult to model, and simple assumptions about 'time as number of years' that are amenable to a variety of models. Most political science research designs are 
based on short-term cause and short-term outcome. Thus, they are by and large representing a snapshot of an actual process or outcome for a given brief time span. Pierson (2004: 81) argues that "most political processes are necessarily best understood by invoking accounts with this kind of temporal structure" but in other cases there is the need "to extend our temporal field of vision to consider social dynamics $[\ldots]$ over extended periods of time." Certain processes are slow-moving and have long-term outcomes that if taken at a snapshot may affect the integrity of the research. We operationalize this trade-off by separating articles that consider qualitative effects of time from articles that treat time as quantity (number of years). We also have a residual category of articles that are a-temporal; hence they do not deal with time at all.

Mechanism-oriented versus variable-oriented design: The differentiation between mechanism- versus variable-oriented does not necessarily present a trade-off. It is more an issue of prioritizing one or the other. Jon Elster (1989) argues that a fact is 'a temporal snapshot of a stream of events or a pile of such snapshots' and - for the social sciences - 'the elementary events are individual actions' (Elster, 1989: 3). The relation that develops between a set of facts and a set of events is essential to the explanation of a specific event, as the elucidation of why an event occurred can be achieved by 'citing an earlier event as the cause of the event we want to explain, together with some account of the causal mechanism connecting the two events' (Elster, 1989: 3). The following illustration shows the link between variables (facts and events) and the path the links one to another (mechanisms): 


\section{Graph 1: variables and mechanisms.}

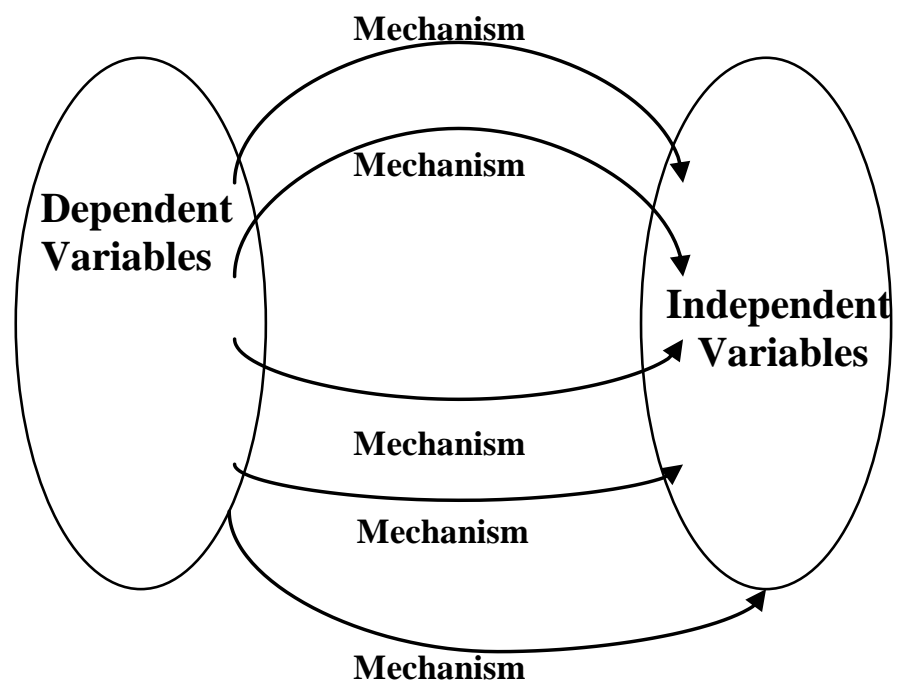

The trade-off lies in the distinction between laws and mechanisms. Variableoriented designs - it has been argued - tend to reflect correlation (C. Ragin, 1987: 166), whereas mechanism-oriented designs have a propensity towards causation. Concentrating on variables - the argument goes on - risks downplaying the role of mechanisms in causal analysis. On the other hand, mechanism-oriented research designs are in danger of neglecting the necessary and sufficient conditions under which these mechanisms are triggered.

Top-down versus bottom-up approach: This is only pertinent to the study of Europeanization because it refers specifically to the orientation of the process itself. We explained it in the previous Section.

\section{Constructing of the samples and findings}

We compiled a first sample on the literature on Europeanization based on the Social Science Citation Index (search on 'Europeani\$ation' AND 'Politics'; period 1997-2007), from which we extracted the most frequently cited articles of the discipline (table 1). To establish whether some features are unique to the field of Europeanization or reflect more general trends in European Studies, a control group is 
needed. For the control group we searched 'European Union' AND 'Politics' in the same index for the same years (table 2). We excluded review articles, normative articles without any empirical analysis, industrial relations articles, and statistical artifacts (there are a few articles with Europeanization somewhere in the abstract but no reference to this topic). We also excluded articles well below the $\mathrm{H}$-index as calculated by the SSCI. This left us with 32 Europeanization articles, cited at least 5 times (table 3). The corresponding total number for the control group was therefore set at 32 as well (table 4$)$.

A quick qualitative look at table 3 and 4 is sufficient to appreciate the diversity between the two fields. First, we expected several double entries (i.e., the same article featuring in the two tables) but this is not the case (Cole and Drake is an exception). It is true, there may be artifacts: if an author uses Europeanization in the abstract, title or key-words, she may not want to use politics AND European integration as well thinking it is redundant. This way her article will feature in one sample but not in the other. This may be why the top articles in the Europeanization sample do not show up in the middle of the control group table. Yet on average, Europeanization articles are still several citations away from the pack of highly cited articles on the politics of European integration. Secondly, Europeanization scholars are disproportionately more interested in policy analysis (including of course regulation, transposition of directives, comitology, and implementation analysis), country-based case studies, and historical narratives. Highly-cited control group articles are much more diverse, with several articles on the substance of law-making and voting in the EU institutions, public opinion, and identity, as well as public policy and modes of governance. 
Table 5 shows journals that have published at least two articles from the sample, with the Journal of European Public Policy dominating both Europeanization and the control group. Articles in the Europeanization sample tend to be clustered around a narrow group of journals. The control group refers to a more diverse set of journals. Fig. 1 portrays citations by year of publication - it shows that 21 of the 32 Europeanization articles were published in three years (2000, 2001, and 2002). The pattern for the control group is more even. In both cases, it takes some five-six years to an article to gain a high number of citations.

We created a scorecard which included the six trade-offs - plus the trade-off specific to Europeanization studies only for sample A. Each trade off was split into three categories. If an observation was in accordance with one of the two options of the trade-off it was marked with the value " 1 ", otherwise it was marked with " 0 ". Observations that fell under the "not applicable" option were marked with a "-1" value, although in the data analysis the category was not considered as a 'missing case'. In terms of scoring the actual sample, upon construction of the survey protocol, we employed ourselves as the two coders and utilized inter-coder reliability. Intercoder reliability may not increase the validity of the actual scoring in a sample size similar to ones of this exercise, but it increases transparency and congruence (Krippendorf, 2004). We scored the articles once for a pilot exercise (to test our criteria and definitions on the road), then we refined our criteria and scored a second time, in April-May 2008.

As mentioned, the first issue we address is about the overall awareness of research design issues in the Europeanization literature. When we started coding, it turned out that most of the articles do not show awareness of the methodological trade-offs mentioned above. The authors do not have explicit Sections on research 
design; neither do they discuss whether they are more likely to have a problem of multi-collinearity or a problem of omitted variables bias. In consequence, we had to extrapolate the choice made by the author in terms of research design by carefully considering the empirical evidence. We used the empirical analysis presented in the articles as "revealed preference" of the methodological choices made by the authors. To defend this choice, we argue that no matter how much an author is aware of a methodological trade-off, in order to perform analysis she must have made some implicit choice.

The same problem applies to the control group of European integration articles: it is hard to detect an interest in causal analysis and trade-offs and an acknowledgement of the methodological issues at stake in most of the papers. In this respect, Europeanization and the wider category of European integration have the same features. In some cases, however, the trade-offs are genuinely not applicable to the study in question 0 hence a value of -1 .

Turning to findings, table 6 compares the results for sample A (that is, Europeanization) and sample B (our control group). Tables 7 and 8 show the correlation between the trade-offs. Following the argument of Mahoney and Goertz that all trade-offs reflect a major fracture between qualitative versus quantitative, one would expect strong correlation between the six trade-offs (the seventh trade-off used in the Europeanization sample is not interesting in this respect). However, the correlation matrices in tables 8 and 9 do not support this argument. Tables 9 and 10 provide the more fine-grained information used to compile the summative results of table 6. Table 9, in particular, shows that most Europeanization articles are based on the top-down research design (21 against 5). 
Let us now look at Europeanization and control group together (table 6). Both samples show a balanced distribution between cause of effects and effects of causes the control group with a slight orientation towards the former. Turning to the trade-off between concept and measurement, we expected to find Europeanization articles more interested in developing the concept rather than measurement, and the opposite for the control group. This is because the field of Europeanization is relatively new. Hence we reasoned - researchers will spend more time in discussing their concepts. In addition, the review articles on Europeanization (Lenschow, 2005; Olsen, 2002; Radaelli, 2003) suggest that definitional issues and concept formation have somewhat been prominent. The highly-cited articles, by contrast, seem to suggest that there is a preference for measurement. This characteristic features also in the control group.

On the type of causation (table 6: column 4), yet again the two samples do not show much difference, although Europeanization articles have a slight preference for complex notions of causation. This is arguably the result of a field of research that was literary created around a causation puzzle: how can one grasp the essence of the Europeanization process if there are multiple feedback loops between domestic and EU variables in this process (Radaelli, 2003)? Unsurprisingly, researchers are working with complex notions of causation in this area. Singular causation is preferred by those who think of Europeanization as implementation of EU decisions for these authors causation is more straightforward.

Both Europeanization and control group seem to prefer a rich set of explanatory variables to parsimony (table 6: column 4). Regarding time (table 6: column 5) the Europeanization sample deals with the qualitative aspects of this variable more than the control group. The difference is small, however. It can be explained by noting that several articles on Europeanization are based on policy 
analysis, longitudinal case studies and-or process tracing. Since the debate on Europeanization has spent much time discussing how exactly this process works, there is a major emphasis on mechanisms that we do not find in the control group (table 6: column 6).

\section{Concluding Remarks}

In this paper, we have used basic meta-analysis to examine Europeanization. This technique has been rarely used in this field, since previous work has been more interested in either discussing outcomes (that is, whether country A is Europeanized or not) or issues of research design at a fairly general level. With our approach, instead, we can connect the theoretical discussion to empirics, and provide a synthetic overview of what goes on in the field in terms of trade-offs in causal analysis.

We addressed three issues: what is the level of awareness of research design in Europeanization? What are the methodological choices made by the scholars in this field? And finally, is there any original contribution that Europeanization can make to the research design debate?

The findings seem to suggest that awareness of research design issues is still low in the field of Europeanization. As coders, one of our major problems was to find out just how an author had gone about the trade-offs, since in most cases awareness of this type of choice was not evident. Hence in most cases we had to infer from the substantive parts of the article the choices made by the author in terms of causal analysis.

Europeanization scholars do not systematically prefer cause-of-effects analysis to effects-of-causes. Measurement features more prominently than conceptual development. Complex notions of causality prevail in the sample, but the difference is slight. On the trade-off between parsimony and rich set of variables, Europeanization 
highly-cited articles go for the latter. They are also engaged with time making qualitative impacts on politics and public policy. Finally, the design shows slight preference for mechanisms-oriented analysis.

To what extent are these features unique to Europeanization? Or do they reflect general patterns in the study of EU politics? The Europeanization sample does not seem to be majorly different from the control group in relation to four of the six trade-offs. However, the samples differ in their choice of mechanisms vs. variables and approach to time.

The methodological discussions within Europeanization have generated a few innovative ideas, such as the insights on mechanisms through which causality works; how to measure the net impact by looking at control groups and test cases from outside the EU; and the notion of bottom-up research design. However, the vast majority of scholars work with rather standard top-down designs. This debate will have to be re-connected to classic methodological debates in comparative politics and international relations - to mention one option, the second-image reversed.

Future work will have to establish if the trade-offs are independent or some of them are correlated. Our analysis suggests that they are not correlated and do not represent manifestations of a more fundamental fracture between quantitative methods and qualitative approaches. 


\section{REFERENCES}

Börzel, T. A. (2005). Mind the gap! European integration between level and scope. Journal of European Public Policy, 12(2), 217-236.

Börzel, T. A., \& Risse, T. (2003). Conceptualizing the domestic impact. In K. Featherstone \& C. Radaelli (Eds.), The Politics of Europeanization (pp. 5780). Oxford: Oxford University Press.

Brady, H., \& Collier, D. (2004). Rethinking Social Inquiry: Diverse Tools, Shared Standards. Oxford: Rowman and Littlefield.

Brady, H., Collier, D., \& Seawright, J. (2006). Toward a pluralistic vision of methodology. Political Analysis, 14, 353.

Bulmer, S., \& Radaelli, C. (2005). The Europeanization of National Policy. In S. Bulmer \& C. Lequesne (Eds.), The Member States of the European Union (pp. 338-359). Oxford: Oxford University Press.

Caporaso, J. A. (2007). The Three Worlds of Regional Integration Theory. In P. Graziano \& M. P. Vink (Eds.), Europeanization: New Research Agendas (pp. 22-34). Basingstoke: Palgrave/Macmillan.

Dyson, K. (2000). EMU as Europeanization: Convergence, diversity and contingency. Journal of Common Market Studies, 38(4), 645-666.

Dyson, K. (Ed.). (2002). European States and the Euro. Oxford: Oxford University Press.

Elmore, R. F. (1982/1999). Background mapping: implementation research and policy decisions. In T. Miyakawa (Ed.), The Science of Public Policy (pp. 80-96). New York: Routledge.

Elster, J. (1989). Nuts and Bolts for the Social Sciences. Cambridge: Cambridge University Press.

Franchino, F. (2005). The study of EU public policy - Results of a survey. European Union Politics, 6(2), 243-252.

Gerring, J. (2001). Social Science Methodology: A criterial framework. Cambridge: Cambridge University Press.

Goetz, K. (2006). Temporality and the European Administrative Space, Paper presented at the CONNEX Thematic Conference TOWARDS A EUROPEAN ADMINISTRATIVE SPACE London.

Graziano, P., \& Vink, M. P. (2007). Europeanization: New Research Agendas. Basingstoke: Palgrave/Macmillan.

Hall, P. A. (2003). Aligning Ontology and Methodology in Comparative Research. In J. Mahoney \& D. Rueschmeyer (Eds.), Comparative Historical Analysis in the Social Science (pp. 373-404). Cambridge: Cambridge University Press.

Hassenteufel, P., \& Surel, Y. (2000). Des politiques publiques comme les autres? Construction de l'objet et outils d'analyse des politiques européennes. Politique européene, 1, 8-24.

Héritier, A., Kerwer, D., Knill, C., Lehmkuhl, D., \& Teutsch, M. (2001). Differential Europe-New Opportunities and Restrictions for Policy Making in Member States. Lanham, MD: Rowman and Littlefield.

Kassim, H. (2005). The Europeanization of Member State Institutions. In S. Bulmer \& C. Lequesne (Eds.), The Member States of the European Union (pp. 285316). Oxford: Oxford University Press.

King, G., Keohane, R. O., \& Verba, S. (1994). Designing Social Inquiry: scientific inference in qualitative research. Princeton, NJ: Princeton University Press. 
Knill, C., \& Lehmkuhl, D. (2002). The national impact of European Union regulatory policy: Three Europeanization mechanisms. European Journal of Political Research, 41(2), 255-280.

Krippendorf, K. (2004). Content analysis: an introduction to its methodology (2nd ed.). London: Sage Publications.

Ladrech, R. (2005). The Europeanization of Interest Groups and Political Parties In S. Bulmer \& C. Lequesne (Eds.), The Member States of the European Union (pp. 317-337). Oxford: Oxford University Press.

Lenschow, A. (2005). Europeanisation of public policy. In J. J. Richardson (Ed.), European Union: Power and Policy-Making (3rd ed., pp. 55-71). Abingdon: Routledge.

Levi-Faur, D. (2004). On the 'net impact' of Europeanization: the EU's telecom and electricity regimes between the global and the national. Comparative Political Studies, 37(1), 3-29.

Lipsey, M. W., \& Wilson, D. B. (2001). Practical meta-analysis. Thousand Oaks, CA: Sage Publications.

Mahoney, J., \& Goertz, G. (2006). A tale of two cultures: contrasting quantitative and qualitative research. Political Analysis, 14, 227-249.

Olsen, J. P. (1995a). Europeam challenges to the nation state. Oslo: ARENA, Working Paper No. 14.

Olsen, J. P. (1995b). Europeanization and nation-state dynamics. Oslo: ARENA, Working Paper No. 9.

Olsen, J. P. (2002). The many faces of Europeanization. Journal of Common Market Studies, 40(5), 921-952.

Pierson, P. (1996). The path to European integration. A historical institutional analysis, Comparative Political Studies. Comparative Political Studies, 29 (2) April, 123-163.

Pierson, P. (2004). Politics in time: history, institutions and social analysis. Princeton, NJ: Princeton University Press.

Radaelli, C. (2003). The Europeanization of public policy. In K. Featherstone \& C. Radaelli (Eds.), The Politics of Europeanization (pp. 27-56). Oxford: Oxford University Press.

Radaelli, C., \& Pasquier, R. (2007). Conceptual Issues. In M. P. Vink \& P. Graziano (Eds.), Europeanization: New research agendas (pp. 35-45). Basingstoke: Palgrave/Macmillan.

Ragin, C. (1987). The comparative method: moving beyond qualitative and quantitative strategies. Berkeley, CA: University of California Press.

Ragin, C. C. (2000). Fuzzy-set social science. Chicago: University of Chicago Press.

Saurugger, S. (2005). Europeanization as a methodological challenge: The case of interest groups. Journal of Comparative Policy Analysis, 7(4), 291-312.

Schimmelfennig, F. (2007). European regional organizations, political conditionality, and democratic transformation in Eastern Europe. East European Politics and Societies, 21(1), 126-141.

Schmidt, V. A. (2002). Europeanization and the mechanics of economic policy adjustment. Journal of European Public Policy, 9(6), 894-912.

Schmidt, V. A. (2006). Give peace a chance: Reconciling four (not three) "New Institutionalisms", Annual Meeting of the American Political Science Association. Marriot, Lowes Philadelphia, and the Pennsylvania Convention Center, Philadelphia, PA. 
Sedelmeier, U. (2006). Europeanisation in new member and candidate states. Living Reviews in European Governance, 1(3).

Stolfi, F. (2008). The Europeanization of Italy's Budget Institutions in the 1990s. Journal of European Public Policy, 15(4). 


\section{APPENDIX}

Table 1: List of most cited articles on Europeanization (cut-off point at 5 citations)

\begin{tabular}{|c|c|c|c|c|c|}
\hline & Author & Title & Journal & Year & $\begin{array}{l}\text { Times } \\
\text { Cited } \\
\end{array}$ \\
\hline 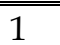 & Olsen, JP & "The many faces of Europeanization & JCMS 40(5) & 2002 & 39 \\
\hline 2 & Scharpf, FW & $\begin{array}{l}\text { Economic integration democracy and the } \\
\text { welfare state }\end{array}$ & JEPP 4(1) & 1997 & 39 \\
\hline 3 & Börzel, TA & $\begin{array}{l}\text { Towards convergence in Europe? } \\
\text { Institutional adaptation to Europeanization in } \\
\text { Germany and Spain }\end{array}$ & JCMS 37(4) & 1999 & 38 \\
\hline 4 & Jachtenfuchs, M & $\begin{array}{l}\text { The governance approach to European } \\
\text { integration }\end{array}$ & JCMS 39(2) & 2001 & 32 \\
\hline 5 & Grabbe, $\mathrm{H}$ & $\begin{array}{l}\text { How does Europeanization affect CEE } \\
\text { governance? Conditionality, diffusion and } \\
\text { diversity }\end{array}$ & JEPP 8(6) & 2001 & 31 \\
\hline 6 & $\begin{array}{l}\text { Benz, A; } \\
\text { Eberlein, B }\end{array}$ & $\begin{array}{l}\text { The Europeanization of regional policies: } \\
\text { patterns of multi-level governance }\end{array}$ & JEPP 6(2) & 1999 & 29 \\
\hline 7 & Mazey, S & $\begin{array}{l}\text { The European Union and women's rights: } \\
\text { from the Europeanization of national agendas } \\
\text { to the nationalization of a European agenda }\end{array}$ & JEPP 5(1) & 1998 & 28 \\
\hline 8 & $\begin{array}{l}\text { Knill, C; } \\
\text { Lehmkuhl, D }\end{array}$ & $\begin{array}{l}\text { The national impact of European Union } \\
\text { regulatory policy: Three Europeanization } \\
\text { mechanisms }\end{array}$ & EJPR (41(2) & 2002 & 26 \\
\hline 9 & Wessels, W & $\begin{array}{l}\text { Comitology: Fusion in action. Politico- } \\
\text { administrative trends in the EU system }\end{array}$ & JEPP 5(2) & 1998 & 23 \\
\hline 10 & Börzel, TA & $\begin{array}{l}\text { Pace-setting, foot-dragging, and fence-sitting: } \\
\text { Member state responses to Europeanization }\end{array}$ & JCMS 40(2) & 2002 & 21 \\
\hline 11 & Richardson, J & $\begin{array}{l}\text { Government, interest group and policy } \\
\text { change }\end{array}$ & $\begin{array}{l}\text { Political Studies } \\
48(5)\end{array}$ & 2000 & 21 \\
\hline 12 & $\begin{array}{l}\text { Marcussen, M; } \\
\text { Risse, T; } \\
\text { Engelmann- } \\
\text { Martin, D; et al. }\end{array}$ & $\begin{array}{l}\text { Constructing Europe? The evolution of } \\
\text { French, British and German nation state } \\
\text { identities }\end{array}$ & JEPP 6(4) & 1999 & 18 \\
\hline 13 & Harmsen, R & $\begin{array}{l}\text { The Europeanization of national } \\
\text { administrations: A comparative study of } \\
\text { France and the Netherlands }\end{array}$ & Governance 12(1) & 1999 & 18 \\
\hline 14 & $\begin{array}{l}\text { Lippert, B; } \\
\text { Umbach, G; } \\
\text { Wessels, W }\end{array}$ & $\begin{array}{l}\text { Europeanization of CEE executives: EU } \\
\text { membership negotiations as a shaping power }\end{array}$ & JEPP 8(6) & 2001 & 17 \\
\hline 15 & Goetz, KH & $\begin{array}{l}\text { Making sense of post-communist central } \\
\text { administration: modernization, } \\
\text { Europeanization or Latinization? }\end{array}$ & JEPP 8(6) & 2001 & 17 \\
\hline 16 & $\begin{array}{l}\text { Gollbach, J; } \\
\text { Schulten, T }\end{array}$ & $\begin{array}{l}\text { Cross-border collective bargaining networks } \\
\text { in Europe }\end{array}$ & $\begin{array}{l}\text { European Journal } \\
\text { of Industrial } \\
\text { Relations 6(2) }\end{array}$ & 2000 & 17 \\
\hline 17 & Wills, J & $\begin{array}{l}\text { Great expectations: Three years in the life of a } \\
\text { European Woks Council }\end{array}$ & $\begin{array}{l}\text { European Journal } \\
\text { of Industrial } \\
\text { Relations 6(1) } \\
\end{array}$ & 2000 & 17 \\
\hline 18 & $\begin{array}{l}\text { Holzinger, K; } \\
\text { Knill, C }\end{array}$ & $\begin{array}{l}\text { Causes and conditions of cross-national } \\
\text { policy convergence }\end{array}$ & JEPP 12(5) & 2005 & 16 \\
\hline
\end{tabular}




\begin{tabular}{|c|c|c|c|c|c|}
\hline 19 & Knill, C & $\begin{array}{l}\text { Introduction: Cross-national policy } \\
\text { convergence: concepts, approaches and } \\
\text { explanatory factors }\end{array}$ & JEPP 12(5) & 2005 & 15 \\
\hline 20 & $\begin{array}{l}\text { Borraz, O; } \\
\text { John, P }\end{array}$ & $\begin{array}{l}\text { The transformation of urban political } \\
\text { leadership in Western Europe }\end{array}$ & $\begin{array}{l}\text { Int'1 Journal of } \\
\text { Urban and } \\
\text { Regional } \\
\text { Research 28(1) }\end{array}$ & 2004 & 14 \\
\hline 21 & $\begin{array}{l}\text { Cole, } \mathrm{A} ; \\
\text { Drake, } \mathrm{H}\end{array}$ & $\begin{array}{l}\text { The Europeanization of the French polity: } \\
\text { continuity, change and adaptation }\end{array}$ & JEPP 7(1) & 2000 & 14 \\
\hline 22 & Schmidt, VA & $\begin{array}{l}\text { Europeanization and the mechanisms of } \\
\text { economic policy adjustment }\end{array}$ & JEPP 9(6) & 2002 & 13 \\
\hline 23 & Bursens, $\mathrm{P}$ & $\begin{array}{l}\text { Why Denmark and Belgium have different } \\
\text { implementation records: On transposition } \\
\text { laggards and leaders in the EU }\end{array}$ & $\begin{array}{l}\text { Scandinavian } \\
\text { Political Studies } \\
\text { 25(2) }\end{array}$ & 2002 & 13 \\
\hline 24 & Lavenex, S & $\begin{array}{l}\text { The Europeanization of refugee policies: } \\
\text { Normative challenges and institutional } \\
\text { legacies }\end{array}$ & JCMS 39(5) & 2001 & 13 \\
\hline 25 & Agh, A & $\begin{array}{l}\text { Europeanization of policy-making in East } \\
\text { Central Europe: the Hungarian approach to } \\
\text { EU accession }\end{array}$ & JEPP 6(5) & 1999 & 13 \\
\hline 26 & Gilardi, F & $\begin{array}{l}\text { The institutional foundations of regulatory } \\
\text { capitalism: The diffusion of independent } \\
\text { regulatory agencies in western Europe }\end{array}$ & $\begin{array}{l}\text { Annals of the } \\
\text { American } \\
\text { Academy of } \\
\text { Political and } \\
\text { Social Science } 598 \\
\end{array}$ & 2005 & 12 \\
\hline 27 & Andersen, MS & $\begin{array}{l}\text { Ecological modernization or subversion? The } \\
\text { effect of Europeanization on Eastern Europe }\end{array}$ & $\begin{array}{l}\text { American } \\
\text { Behavioral } \\
\text { Scientist 45(9) } \\
\end{array}$ & 2002 & 12 \\
\hline 28 & Radaelli, CM & $\begin{array}{l}\text { How does Europeanization produce domestic } \\
\text { policy change? Corporate tax policy in Italy } \\
\text { and the United Kingdom }\end{array}$ & CPS 30(5) & 1997 & 12 \\
\hline 29 & Dimitrova, A & $\begin{array}{l}\text { Enlargement, institution-building and the } \\
\text { EU's administrative capacity requirement }\end{array}$ & WEP 25(4) & 2002 & 11 \\
\hline 30 & Sitter, N & $\begin{array}{l}\text { The politics of opposition and European } \\
\text { integration in Scandinavia: Is Euro-scepticism } \\
\text { a government-opposition dynamic? }\end{array}$ & WEP 24(4) & 2001 & 11 \\
\hline 31 & $\begin{array}{l}\text { Semetko, HA; } \\
\text { De Vreese, CH; } \\
\text { Meter, J }\end{array}$ & $\begin{array}{l}\text { Europeanised politics - Europeanised media? } \\
\text { European integration and political } \\
\text { communication }\end{array}$ & WEP 23(4) & 2000 & 11 \\
\hline 32 & Dyson, $\mathrm{K}$ & $\begin{array}{l}\text { EMU as Europeanization: Convergence, } \\
\text { diversity and contingency }\end{array}$ & JCMS 38(4) & 2000 & 11 \\
\hline 33 & Levi-Faur, D & $\begin{array}{l}\text { On the net impact of Europeanization - The } \\
\text { EU's telecoms and electricity regimes: } \\
\text { between the global and the national }\end{array}$ & CPS 37(1) & 2004 & 10 \\
\hline 34 & Meardi, G & $\begin{array}{l}\text { The trojan horse for the Americanization of } \\
\text { Europe? Polish industrial relations towards } \\
\text { the EU }\end{array}$ & $\begin{array}{l}\text { European Journal } \\
\text { of Industrial } \\
\text { Relations } 8(1)\end{array}$ & 2002 & 10 \\
\hline 35 & $\begin{array}{l}\text { Keller, B; } \\
\text { Sorries B }\end{array}$ & $\begin{array}{l}\text { The sectoral social dialogue and European } \\
\text { social policy: more fantasy, fewer facts }\end{array}$ & $\begin{array}{l}\text { European Journal } \\
\text { of Industrial } \\
\text { Relations } 4(3)\end{array}$ & 1998 & 10 \\
\hline 36 & $\begin{array}{l}\text { John, P; } \\
\text { Whitehead, A }\end{array}$ & $\begin{array}{l}\text { The renaissance of English regionalism in the } \\
\text { 1990s }\end{array}$ & $\begin{array}{l}\text { Policy and } \\
\text { Politics 25(1) }\end{array}$ & 1997 & 10 \\
\hline
\end{tabular}




\begin{tabular}{|c|c|c|c|c|c|}
\hline 37 & $\begin{array}{l}\text { Schimmelfennig, } \\
\text { F; } \\
\text { Sedelmeier, U }\end{array}$ & $\begin{array}{l}\text { Governance by conditionality: EU rule } \\
\text { transfer to the candidate countries of Central } \\
\text { and Eastern Europe }\end{array}$ & JEPP 11(4) & 2004 & 9 \\
\hline 38 & $\begin{array}{l}\text { Schmidt, VA; } \\
\text { Radaelli, CM }\end{array}$ & $\begin{array}{l}\text { Policy change and discourse in Europe: } \\
\text { Conceptual and methodological issues }\end{array}$ & WEP 27(2) & 2004 & 9 \\
\hline 39 & $\begin{array}{l}\text { Williams, AM; } \\
\text { Balaz, V; } \\
\text { Wallace, C }\end{array}$ & $\begin{array}{l}\text { International labour mobility and uneven } \\
\text { regional development in Europe - Human } \\
\text { capital, knowledge and entrepreneurship }\end{array}$ & $\begin{array}{l}\text { European Urban } \\
\text { and Regional } \\
\text { Studies 11(1) }\end{array}$ & 2004 & 9 \\
\hline 40 & Goetz, KH & $\begin{array}{l}\text { European integration and national executives: } \\
\text { A cause in search of an effect? }\end{array}$ & WEP 23(4) & 2000 & 9 \\
\hline 41 & Rosamond, B & $\begin{array}{l}\text { Discourses of globalization and the social } \\
\text { construction of European identities }\end{array}$ & JEPP 6(4) & 1999 & 9 \\
\hline 42 & $\begin{array}{l}\text { Lecher, W; } \\
\text { Rub, S }\end{array}$ & $\begin{array}{l}\text { The constitution of European Works } \\
\text { Councils: From information forum to social } \\
\text { actor? }\end{array}$ & $\begin{array}{l}\text { European Journal } \\
\text { of Industrial } \\
\text { Relations 5(1) }\end{array}$ & 1999 & 9 \\
\hline 43 & Hudson, $\mathrm{R}$ & $\begin{array}{l}\text { Changing industrial production systems and } \\
\text { regional development in the New Europe }\end{array}$ & $\begin{array}{l}\text { Transactions of } \\
\text { the Institute of } \\
\text { British } \\
\text { Geographers }\end{array}$ & 2002 & 8 \\
\hline 44 & Ladrech, R & $\begin{array}{l}\text { Europeanization and political parties - } \\
\text { Towards a framework for analysis }\end{array}$ & Party Politics 8(4) & 2002 & 8 \\
\hline 45 & John, $\mathrm{P}$ & $\begin{array}{l}\text { The Europeanisation of sub-national } \\
\text { governance }\end{array}$ & $\begin{array}{l}\text { Urban Studies } \\
37(5-6)\end{array}$ & 2000 & 8 \\
\hline 46 & $\begin{array}{l}\text { Marginson, } \mathrm{P} ; \\
\text { Sisson, } \mathrm{K} ; \\
\text { Arrowsmith, J }\end{array}$ & $\begin{array}{l}\text { Between decentralization and } \\
\text { Europeanization: sectoral bargaining in four } \\
\text { countries and two sectors }\end{array}$ & $\begin{array}{l}\text { European Journal } \\
\text { of Industrial } \\
\text { Relations } 9(2) \\
\end{array}$ & 2003 & 7 \\
\hline 47 & Falkner, G & $\begin{array}{l}\text { How pervasive are euro-policies? Effects of } \\
\text { EU membership on a new member state }\end{array}$ & JCMS 38(2) & 2000 & 7 \\
\hline 48 & $\begin{array}{l}\text { Eyre, S; } \\
\text { Lodge, M }\end{array}$ & $\begin{array}{l}\text { National tunes and a European melody? } \\
\text { Competition law reform in the UK and } \\
\text { Germany }\end{array}$ & JEPP 7(1) & 2000 & 7 \\
\hline 49 & Mastenbroek, E & EU compliance: Still a ‘black hole'? & JEPP 12(6) & 2005 & 6 \\
\hline 50 & Mair, $\mathrm{P}$ & The Europeanization dimension & JEPP 11(2) & 2004 & 6 \\
\hline 51 & $\begin{array}{l}\text { Sisson, } \mathrm{K} ; \\
\text { Marginson, } \mathrm{P}\end{array}$ & $\begin{array}{l}\text { Co-ordinated bargaining: A process for our } \\
\text { times? }\end{array}$ & $\begin{array}{l}\text { British Journal of } \\
\text { Industrial } \\
\text { Relations } 40(2)\end{array}$ & 2002 & 6 \\
\hline 52 & Warleigh, A & $\begin{array}{l}\text { 'Europeanizing' civil society: NGOs as agents } \\
\text { of political socialization }\end{array}$ & JCMS 39(4) & 2001 & 6 \\
\hline 53 & Cole, A & $\begin{array}{l}\text { National and partisan contexts of } \\
\text { Europeanization: the case of the French } \\
\text { socialists }\end{array}$ & JCMS 39(1) & 2001 & 6 \\
\hline 54 & $\begin{array}{l}\text { Eberlein, B; } \\
\text { Grande, E }\end{array}$ & $\begin{array}{l}\text { Beyond delegation: transnational regulatory } \\
\text { regimes and the EU regulatory state }\end{array}$ & JEPP 12(1) & 2005 & 5 \\
\hline 55 & $\begin{array}{l}\text { Beyers, J; } \\
\text { Trondal, J }\end{array}$ & $\begin{array}{l}\text { How nation states 'hit' Europe: ambiguity } \\
\text { and representation in the European Union }\end{array}$ & WEP 27(5) & 2004 & 5 \\
\hline 56 & Dostal, JM & $\begin{array}{l}\text { Campaigning on expertise: how the OECD } \\
\text { framed EU welfare and labour market } \\
\text { policies - and why success could trigger } \\
\text { failure }\end{array}$ & JEPP 11(3) & 2004 & 5 \\
\hline 57 & $\begin{array}{l}\text { Goldsmith, M; } \\
\text { Larsen, H }\end{array}$ & Local political leadership: Nordic style & $\begin{array}{l}\text { Int'1 Journal of } \\
\text { Urban and } \\
\text { Regional } \\
\text { Research 28(1) }\end{array}$ & 2004 & 5 \\
\hline
\end{tabular}




\begin{tabular}{|c|l|l|l|c|c|}
\hline 58 & Anderson, JJ & $\begin{array}{l}\text { Europeanization and the transformation of } \\
\text { the democratic polity, 1945-2000 }\end{array}$ & JCMS 40(5) & 2002 & 5 \\
\hline 59 & $\begin{array}{l}\text { Fischer, A; } \\
\text { Nicolet, S; } \\
\text { Sciarini, P }\end{array}$ & $\begin{array}{l}\text { Europeanisation of a non-EU country: the } \\
\text { case of Swiss immigration policy }\end{array}$ & WEP 25(4) & 2002 & 5 \\
\hline 60 & Monar, J & $\begin{array}{l}\text { The dynamics of justice and home affairs: } \\
\text { Laboratories, driving factors and costs }\end{array}$ & JCMS 39(4) & 2001 & 5 \\
\hline 61 & Smith, J & $\begin{array}{l}\text { Cultural aspects of Europeanization: The case } \\
\text { of the Scottish Office }\end{array}$ & $\begin{array}{l}\text { Public } \\
\text { Administration } \\
79(1)\end{array}$ & 2001 & 5 \\
\hline 62 & Lodge, M & $\begin{array}{l}\text { Isomorphism of national policies? The } \\
\text { 'Europeanisation' of German competition and } \\
\text { public procurement law }\end{array}$ & WEP 23(1) & 2000 & 5 \\
\hline
\end{tabular}

Source: ISI Web of Knowledge; search terms “Europeani\$ation”; search years 1997-2007; date of last access, 1 February, 2008. 

Table 2: List of most cited articles on European Union and Politics (cut-off
point at 12 citations)

\begin{tabular}{|c|c|c|c|c|c|}
\hline & Author & Title & Journal & Year & $\begin{array}{l}\text { Times } \\
\text { Cited }\end{array}$ \\
\hline 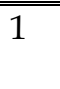 & Sabatier, PA & $\begin{array}{l}\text { The advocacy coalition framework: revisions } \\
\text { and relevance for Europe }\end{array}$ & JEPP 5(1) & 1998 & 84 \\
\hline 2 & Alter, KJ & $\begin{array}{l}\text { Who are the masters of the treaty? European } \\
\text { governments and the European Court of } \\
\text { Justice }\end{array}$ & IO 52(1) & 1998 & 60 \\
\hline 3 & Hix, S & $\begin{array}{l}\text { Dimensions and alignments in European } \\
\text { Union politics: Cognitive constraints and } \\
\text { partisan responses }\end{array}$ & EJPR 35(1) & 1999 & 54 \\
\hline 4 & $\begin{array}{l}\text { Hodson, D; } \\
\text { Maher, I }\end{array}$ & $\begin{array}{l}\text { The open method as a new mode of } \\
\text { governance: The case of soft economic policy } \\
\text { and support for European integration }\end{array}$ & CPS 31(5) & 1998 & 50 \\
\hline 5 & Anderson, CJ & $\begin{array}{l}\text { When in doubt use proxies - Attitudes } \\
\text { toward domestic politics and support for } \\
\text { European integration }\end{array}$ & CPS 31(5) & 1998 & 50 \\
\hline 6 & Taggart, $\mathrm{P}$ & $\begin{array}{l}\text { A touchstone of dissent: Euroscepticism in } \\
\text { contemporary Western European party } \\
\text { systems }\end{array}$ & EJPR 33(3) & 1998 & 48 \\
\hline 7 & Hix, S & $\begin{array}{l}\text { The study of the European Union II: the 'new } \\
\text { governance' agenda and its rival }\end{array}$ & JEPP 5(1) & 1998 & 47 \\
\hline 8 & Keating, M & $\begin{array}{l}\text { The invention of regions: political } \\
\text { restructuring and territorial government in } \\
\text { Western Europe }\end{array}$ & $\begin{array}{l}\text { Environment and } \\
\text { Planning C 15(4) }\end{array}$ & 1997 & 45 \\
\hline 9 & Leitner, $\mathrm{H}$ & $\begin{array}{l}\text { Reconfiguring the spatiality of power: the } \\
\text { construction of a supranational migration } \\
\text { framework for the European Union }\end{array}$ & $\begin{array}{l}\text { Political } \\
\text { Geography 16(2) }\end{array}$ & 1997 & 43 \\
\hline 10 & $\begin{array}{l}\text { Garrett, G; } \\
\text { Keleman, RD; } \\
\text { Schulz, H }\end{array}$ & $\begin{array}{l}\text { The European Court of Justice, national } \\
\text { government, and legal integration in the } \\
\text { European Union }\end{array}$ & IO 52(1) & 1998 & 41 \\
\hline 11 & $\begin{array}{l}\text { Tsebelis, G; } \\
\text { Garrett, G }\end{array}$ & $\begin{array}{l}\text { The institutional foundations of } \\
\text { intergovernmentalism and supranationalism } \\
\text { in the European Union }\end{array}$ & IO 55(2) & 2001 & 39 \\
\hline 12 & Pahre, R & $\begin{array}{l}\text { Endogenous domestic institutions in two- } \\
\text { level games and parliamentary oversight of } \\
\text { the European Union }\end{array}$ & \begin{tabular}{|l|} 
Journal of \\
Conflict \\
Resolution $41(1)$ \\
\end{tabular} & 1997 & 35 \\
\hline 13 & McLaren, LM & $\begin{array}{l}\text { Public support for the European Union: } \\
\text { Cost/ benefit analysis or perceived cultural } \\
\text { threat? }\end{array}$ & $\begin{array}{l}\text { Journal of Politics } \\
64(2)\end{array}$ & 2002 & 32 \\
\hline 14 & Tallberg, J & $\begin{array}{l}\text { Paths to compliance: Enforcement, } \\
\text { management and the European Union }\end{array}$ & IO 56(3) & 2002 & 29 \\
\hline 15 & Huysmans, J & $\begin{array}{l}\text { The European Union and the securitization of } \\
\text { migration }\end{array}$ & JCMS 38(5) & 2000 & 29 \\
\hline 16 & Gabel, MJ & $\begin{array}{l}\text { Economic integration and mass politics: } \\
\text { Market liberalization and public attitudes in } \\
\text { the European Union }\end{array}$ & $\begin{array}{l}\text { American Journal } \\
\text { of Political } \\
\text { Science } 42(3) \\
\end{array}$ & 1998 & 29 \\
\hline 17 & Abbott, KW & $\begin{array}{l}\text { International relations theory, international } \\
\text { law, and the regime governing atrocities in } \\
\text { internal conflicts }\end{array}$ & $\begin{array}{l}\text { American Journal } \\
\text { of Int'1 Law 93(2) }\end{array}$ & 1999 & 28 \\
\hline 18 & $\begin{array}{l}\text { Borras, S; } \\
\text { Jacobsson, K }\end{array}$ & $\begin{array}{l}\text { The open method of co-ordination and new } \\
\text { governance patterns in the EU }\end{array}$ & JEPP 11(2) & 2004 & 26 \\
\hline
\end{tabular}




\begin{tabular}{|c|c|c|c|c|c|}
\hline 19 & Carrubba, CJ & $\begin{array}{l}\text { The electoral connection in European Union } \\
\text { politics }\end{array}$ & $\begin{array}{l}\text { Journal of Politics } \\
63(1)\end{array}$ & 2001 & 26 \\
\hline 20 & $\begin{array}{l}\text { Schimmelfennig, } \\
\text { F }\end{array}$ & $\begin{array}{l}\text { International socialization in the New Europe: } \\
\text { rational action in an institutional environment }\end{array}$ & EJIR 6(1) & 2000 & 25 \\
\hline 21 & Bouwen, $\mathrm{P}$ & $\begin{array}{l}\text { Corporate lobbying in the European Union: } \\
\text { the logic of access }\end{array}$ & JEPP 9(3) & 2002 & 22 \\
\hline 22 & Meyer, C & $\begin{array}{l}\text { Political legitimacy and the invisibility of } \\
\text { politics: Exploring the European Union's } \\
\text { communication deficit }\end{array}$ & JCMS 37(4) & 1999 & 22 \\
\hline 23 & Caporaso, JA & $\begin{array}{l}\text { Across the great divide: integrating } \\
\text { comparative and international politics }\end{array}$ & $\begin{array}{l}\text { Int'1 Studies } \\
\text { Quarterly 41(4) }\end{array}$ & 1997 & 22 \\
\hline 24 & $\begin{array}{l}\text { Jupille, J; } \\
\text { Caporaso, JA; } \\
\text { Checkel, JT }\end{array}$ & $\begin{array}{l}\text { Integrating institutions - rationalism, } \\
\text { constructivism, and the study of the } \\
\text { European Union }\end{array}$ & CPS 36(1-2) & 2003 & 21 \\
\hline 25 & Vogel, D & $\begin{array}{l}\text { The hare and tortoise revisited: the new } \\
\text { politics of consumer and environmental } \\
\text { regulation in Europe }\end{array}$ & BJPS 33 & 2003 & 20 \\
\hline 26 & Smith, A & $\begin{array}{l}\text { Imagining geographies of the 'new Europe': } \\
\text { geo-economic power and the new European } \\
\text { architecture of integration }\end{array}$ & $\begin{array}{l}\text { Political } \\
\text { Geography 21(5) }\end{array}$ & 2002 & 20 \\
\hline 27 & Kohler-Koch, B & $\begin{array}{l}\text { Framing: the bottleneck of constructing } \\
\text { legitimate institutions }\end{array}$ & JEPP 7(4) & 2000 & 20 \\
\hline 28 & $\begin{array}{l}\text { Steunenberg, B; } \\
\text { Schmidtchen, D; } \\
\text { Koboldt, C }\end{array}$ & $\begin{array}{l}\text { Strategic power in the European Union - } \\
\text { Evaluating the distribution of power in policy } \\
\text { games }\end{array}$ & $\begin{array}{l}\text { Journal of } \\
\text { Theoretical } \\
\text { Politics 11(3) }\end{array}$ & 1999 & 20 \\
\hline 29 & Bulkeley, $\mathrm{H}$ & $\begin{array}{l}\text { Reconfiguring environmental governance: } \\
\text { towards a politics of scales and networks }\end{array}$ & $\begin{array}{l}\text { Political } \\
\text { Geography 24(8) }\end{array}$ & 2005 & 18 \\
\hline 30 & Cichowski, RA & $\begin{array}{l}\text { Western dreams, eastern realities - Support } \\
\text { for the European Union in Central and } \\
\text { Eastern Europe }\end{array}$ & CPS 33(10) & 2000 & 18 \\
\hline 31 & $\begin{array}{l}\text { Friis, L; } \\
\text { Murphy, A }\end{array}$ & $\begin{array}{l}\text { The European Union and central and eastern } \\
\text { Europe: Governance and boundaries }\end{array}$ & JCMS 37(2) & 1999 & 18 \\
\hline 32 & Laffan, B & $\begin{array}{l}\text { The European Union: a distinctive model of } \\
\text { internationalization }\end{array}$ & JEPP 5(2) & 1998 & 18 \\
\hline 33 & $\begin{array}{l}\text { Barnett, M; } \\
\text { Duvall, R }\end{array}$ & Power in international politics & IO 59(1) & 2005 & 17 \\
\hline 34 & $\begin{array}{l}\text { Schimmelfennig, } \\
\text { F; } \\
\text { Sedelmeier, U }\end{array}$ & $\begin{array}{l}\text { Theorizing EU enlargement: research focus, } \\
\text { hypotheses and the state of research }\end{array}$ & JEPP 9(4) & 2002 & 17 \\
\hline 35 & Pollack, MA & $\begin{array}{l}\text { Learning from the Americanists (again): } \\
\text { Theory and method in the study of delegation }\end{array}$ & WEP 25(1) & 2001 & 17 \\
\hline 36 & Jordan, A & $\begin{array}{l}\text { The European Union: an evolving system of } \\
\text { multi-level governance... or government? }\end{array}$ & \begin{tabular}{|l|} 
Policy and \\
Politics 29(2)
\end{tabular} & 2001 & 17 \\
\hline 37 & Mazey, S & $\begin{array}{l}\text { Introduction: Integrating gender intellectual } \\
\text { and 'real world' mainstreaming }\end{array}$ & JEPP 7(3) & 2000 & 17 \\
\hline 38 & Verdun, A & $\begin{array}{l}\text { The role of the Delors Committee in the } \\
\text { creation of EMU: an epistemic community? }\end{array}$ & JEPP 6(2) & 1999 & 17 \\
\hline 39 & Joachim, J & $\begin{array}{l}\text { Framing issues and seizing opportunities: the } \\
\text { UN, NGOs and women's rights }\end{array}$ & $\begin{array}{l}\text { Int'1 Studies } \\
\text { Quarterly } 47(2)\end{array}$ & 2003 & 16 \\
\hline 40 & Pollack, MA & $\begin{array}{l}\text { International relations theory and European } \\
\text { integration }\end{array}$ & JCMS 39(2) & 2001 & 16 \\
\hline 41 & Paarlberg, R & $\begin{array}{l}\text { Agricultural policy reform and the Uruguay } \\
\text { Round: Synergistic linkage in a two-level } \\
\text { game? }\end{array}$ & IO 51(3) & 1997 & 16 \\
\hline
\end{tabular}




\begin{tabular}{|c|c|c|c|c|c|}
\hline 42 & Checkel, JT & $\begin{array}{l}\text { International institutions and socialization in } \\
\text { Europe: Introduction and framework }\end{array}$ & IO 59(4) & 2005 & 15 \\
\hline 43 & Mastenbroek, E & $\begin{array}{l}\text { Surviving the deadline - The transposition of } \\
\text { EU directives in the Netherlands }\end{array}$ & EUP 4(4) & 2003 & 15 \\
\hline 44 & $\begin{array}{l}\text { Jupille, J; } \\
\text { Caporaso, JA }\end{array}$ & $\begin{array}{l}\text { Institutionalism and the European Union: } \\
\text { Beyond international relations and } \\
\text { comparative politics }\end{array}$ & $\begin{array}{l}\text { Annual Review } \\
\text { of Political } \\
\text { Science } 2\end{array}$ & 1999 & 15 \\
\hline 45 & $\begin{array}{l}\text { Cole, } \mathrm{A} ; \\
\text { Drake, } \mathrm{H}\end{array}$ & $\begin{array}{l}\text { The Europeanization of French polity: } \\
\text { continuity, change and adaptation }\end{array}$ & JEPP 7(1) & 2000 & 15 \\
\hline 46 & $\begin{array}{l}\text { Pappi, FU; } \\
\text { Henning, CHCA }\end{array}$ & $\begin{array}{l}\text { The organization of influence on the EC's } \\
\text { common agricultural policy: A network } \\
\text { approach }\end{array}$ & EJPR 36(2) & 1999 & 15 \\
\hline 47 & $\begin{array}{l}\text { Risse, T; } \\
\text { Engelmann- } \\
\text { Martin, D; } \\
\text { Knopf, HJ; et al. }\end{array}$ & $\begin{array}{l}\text { To Euro or not to Euro? The EMU and } \\
\text { identity politics in the European Union }\end{array}$ & EJIR 5(2) & 1999 & 15 \\
\hline 48 & Haas, PM & $\begin{array}{l}\text { Compliance with EU directives: insights from } \\
\text { international relations and comparative } \\
\text { politics }\end{array}$ & JEPP 5(1) & 1998 & 15 \\
\hline 49 & Selck, TJ & $\begin{array}{l}\text { On the dimensionality of European Union } \\
\text { legislative decision-making }\end{array}$ & \begin{tabular}{|l} 
Journal of \\
Theoretical \\
Politics 16(2)
\end{tabular} & 2004 & 14 \\
\hline 50 & $\begin{array}{l}\text { Lord, C; } \\
\text { Beetham, D }\end{array}$ & $\begin{array}{l}\text { Legitimizing the EU: is there a 'post- } \\
\text { parliamentary basis' for its legitimation? }\end{array}$ & JCMS 39(3) & 2001 & 14 \\
\hline 51 & $\begin{array}{l}\text { Selck, TJ; } \\
\text { Steunenberg, B }\end{array}$ & $\begin{array}{l}\text { Between power and luck - The European } \\
\text { Parliament in the EU legislative process }\end{array}$ & EUP 5(1) & 2004 & 13 \\
\hline 52 & Spanou, C & $\begin{array}{l}\text { European integration in administrative terms: } \\
\text { a framework for analysis and the Greek case }\end{array}$ & JEPP 5(3) & 1998 & 13 \\
\hline 53 & Smith, ME & $\begin{array}{l}\text { Conforming to Europe: the domestic impact } \\
\text { of EU foreign policy co-operation }\end{array}$ & JEPP 7(4) & 2000 & 12 \\
\hline 54 & Boyle, M & $\begin{array}{l}\text { Euro-regionalism and struggles over scales of } \\
\text { governance; the politics of Ireland's } \\
\text { regionalisation approach to Structural Funds } \\
\text { Allocations 2000-2006 }\end{array}$ & $\begin{array}{l}\text { Political } \\
\text { Geography 19(6) }\end{array}$ & 2000 & 12 \\
\hline 55 & $\begin{array}{l}\text { Coleman, WD; } \\
\text { Atkinson, MM; } \\
\text { Montpetit E }\end{array}$ & $\begin{array}{l}\text { Against the odds - Retrenchment in } \\
\text { agriculture in France and the United States }\end{array}$ & $\begin{array}{l}\text { World Politics } \\
49(4)\end{array}$ & 1997 & 12 \\
\hline
\end{tabular}

Source: ISI Web of Knowledge; search terms "European Union" AND "Politics"; search years 1997-2007; date of last access, 1 February, 2008. 
Table 3: List of cases in the Europeanization Sample $(\mathbf{N}=32)$

\begin{tabular}{|l|l|c|c|}
\hline Author & Journal & Year & $\begin{array}{c}\text { Times } \\
\text { Cited }\end{array}$ \\
\hline \hline Scharpf & JEPP & 1997 & 39 \\
\hline Borzel & JCMS & 1999 & 38 \\
\hline Grabbe & JEPP & 2001 & 31 \\
\hline Benz and Eberlein & JEPP & 1999 & 29 \\
\hline Knill and Lehmkuhl & EJPR & 2002 & 26 \\
\hline Borzel & JCMS & 2002 & 21 \\
\hline Harmsen & Governance & 1999 & 18 \\
\hline Marcussen; Risse; Engelman-Martin et al. & JEPP & 1999 & 18 \\
\hline Lippert; Umbach; Wessels & JEPP & 2001 & 17 \\
\hline Cole and Drake & JEPP & 2000 & 14 \\
\hline Agh & JEPP & 1999 & 13 \\
\hline Bursens & Scandinavian Pol Studies & 2002 & 13 \\
\hline Lavenex & JCMS & 2001 & 13 \\
\hline Schmidt VA & JEPP & 2002 & 13 \\
\hline Andersen & Am Beh Scientist & 2002 & 12 \\
\hline Gilardi F & Annals of Am Ac of Pol Soc Sci & 2005 & 12 \\
\hline Radaelli CM & CPS & 1997 & 12 \\
\hline Dimitrova & WEP & 2002 & 11 \\
\hline Dyson K & JCMS & 2000 & 11 \\
\hline Semetko; De Vresse; Peter J & WEP & 2000 & 11 \\
\hline Levi-Faur & CPS & 2004 & 10 \\
\hline Schimmelfennig and Sedelmeier & JEPP & 2004 & 9 \\
\hline Ladrech R & Party Politics & 2002 & 8 \\
\hline Eyre and Lodge & JEPP & 2000 & 7 \\
\hline Falkner G & JCMS & 2000 & 7 \\
\hline Cole & JCMS & 2001 & 6 \\
\hline Warleigh A & JCMS & 2001 & 6 \\
\hline Anderson JJ & JCMS & 2002 & 5 \\
\hline Beyers and Trondal & WEP & 2004 & 5 \\
\hline Fischer; Nicolet; Sciarini & WEP & 2002 & 5 \\
\hline Lodge M & WEP & 2000 & 5 \\
\hline Smith J & PA & 2001 & 5 \\
\hline & & \\
\hline
\end{tabular}

Source: from Table 1 
Table 4: List of cases in the Control Group sample $(\mathbf{N}=32)$

\begin{tabular}{|l|l|c|c|}
\hline Author & Journal & Year & $\begin{array}{c}\text { Times } \\
\text { Cited }\end{array}$ \\
\hline Alter KJ & IO & 1998 & 60 \\
\hline Hix & EJPR & 1999 & 54 \\
\hline Hodson and Maher & JCMS & 2001 & 50 \\
\hline Anderson CJ & CPS & 1998 & 50 \\
\hline Taggart & EJPR & 1998 & 48 \\
\hline Keating M & Environment and Planning C & 1997 & 45 \\
\hline Leitner & Political Geography & 1997 & 43 \\
\hline Garrett; Kelemen; Schulz & IO & 1998 & 41 \\
\hline Pahre & Journal of Conflict Resolution & 1997 & 35 \\
\hline McLaren LM & Journal of Politics & 2002 & 32 \\
\hline Tallberg & IO & 2002 & 29 \\
\hline Huysmans & JCMS & 2000 & 29 \\
\hline Gabel MJ & AJPS & 1998 & 29 \\
\hline Carrubba CJ & Journal of Politics & 2001 & 26 \\
\hline Schimmelfennig & EJIR & 2000 & 25 \\
\hline Bouwen & JEPP & 2002 & 22 \\
\hline Meyer C & JCMS & 1999 & 22 \\
\hline Vogel D & BJPS & 2003 & 20 \\
\hline Smith A & Political Geography & 2002 & 20 \\
\hline Cichowski & CPS & 2000 & 18 \\
\hline Friis and Murphy & JCMS & 1999 & 18 \\
\hline Verdun A & JEPP & 1999 & 17 \\
\hline Paarberg R & IO & 1997 & 16 \\
\hline Mastenbroek & EUP & 2003 & 15 \\
\hline Cole and Drake & JEPP & 2000 & 15 \\
\hline Pappi and Henning & EJPR & 1999 & 15 \\
\hline Risse; Engelmann-Martin; Knopf et al. & EJIR & 1999 & 15 \\
\hline Haas PM & JEPP & 1998 & 15 \\
\hline Selck TJ & Journal of Theoretical Politics & 2004 & 14 \\
\hline Selck TJ and Steunenberg & EUP & 2004 & 13 \\
\hline Spanou C & JEPP & 1998 & 13 \\
\hline Smith ME & JEPP & 2000 & 12 \\
\hline & & & \\
\hline & & 29 \\
\hline
\end{tabular}

Source: from Table 2 
Table 5: Comparative table of articles that by top journals (journals with only one article are not considered)

\begin{tabular}{|l|c|}
\hline \multicolumn{2}{|l|}{ Europeanization Sample } \\
\hline \hline Journal & Articles \\
\hline \hline JEPP & 10 \\
\hline JCMS & 8 \\
\hline WEP & 5 \\
\hline CPS & 2 \\
\hline Other & 7 \\
\hline
\end{tabular}

\begin{tabular}{|l|c|}
\hline \multicolumn{2}{|l|}{ Control Group Sample } \\
\hline Journal & Articles \\
\hline JEPP & 6 \\
\hline IO & 4 \\
\hline JCMS & 4 \\
\hline EJPR & 3 \\
\hline Political Geography & 2 \\
\hline CPS & 2 \\
\hline EJIR & 2 \\
\hline EUP & 2 \\
\hline Journal of Politics & 2 \\
\hline Other & 5 \\
\hline
\end{tabular}


Figure 1: Most cited articles by year of publication

\section{Europeanization Sample \\ by year published}

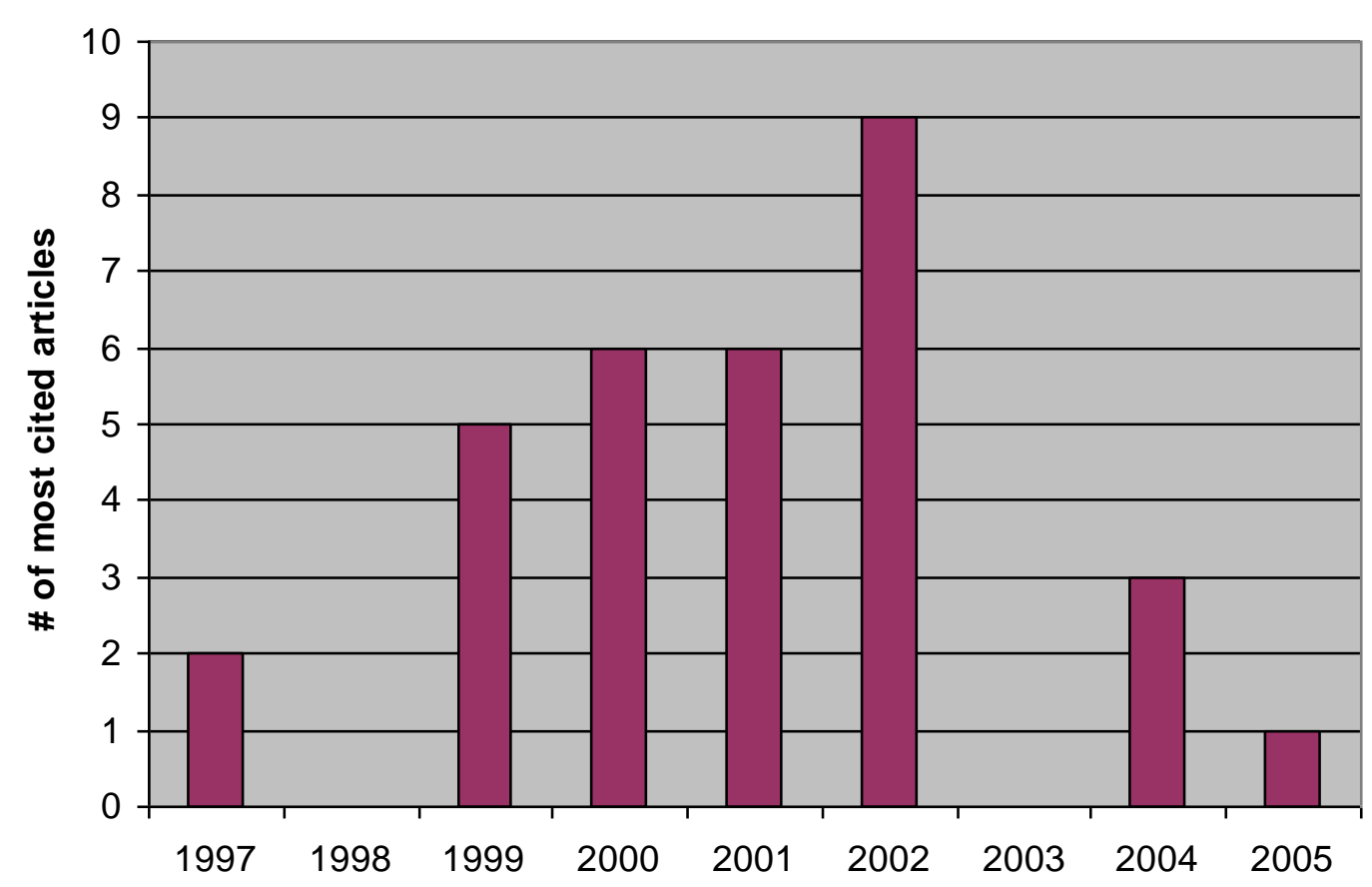

Table 6: Comparative table of the two scorecards

\begin{tabular}{|c|c|c|c|c|c|c|c|c|c|c|c|c|c|c|c|c|c|c|c|}
\hline \multirow[b]{3}{*}{ D } & & \multicolumn{18}{|c|}{ TRADE-OFFS IN CAUSAL ANALYSIS } \\
\hline & & & 1 & & & 2 & & & 3 & & & 4 & & & 5 & & & 6 & \\
\hline & SAMPLE & 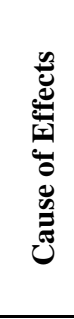 & 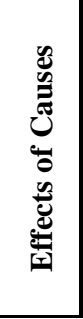 & $\widehat{z}$ & 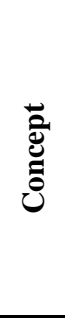 & 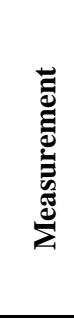 & $\overleftrightarrow{Z}$ & 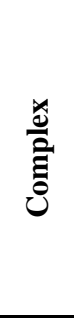 & 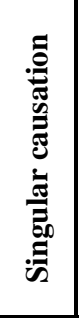 & $\mathbb{z}$ & 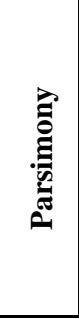 & 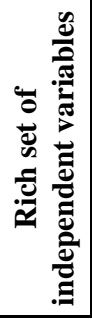 & $\mathbb{z}$ & 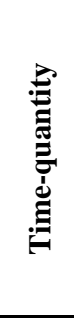 & 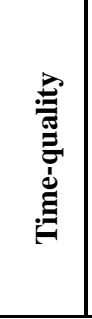 & $\overleftrightarrow{z}$ & 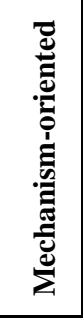 & 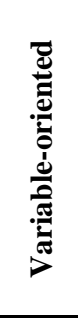 & $\overleftrightarrow{z}$ \\
\hline 1 & $\begin{array}{l}\begin{array}{l}\text { Sample A } \\
(\mathrm{N}=32)\end{array} \\
\end{array}$ & 16 & 16 & $\mathbf{0}$ & 9 & 23 & $\mathbf{0}$ & 16 & 12 & 4 & 9 & 19 & 4 & 12 & 15 & 5 & 18 & 14 & $\mathbf{0}$ \\
\hline 2 & $\begin{array}{l}\text { Sample B } \\
(\mathrm{N}=32)\end{array}$ & 17 & 14 & 1 & 8 & 24 & $\mathbf{0}$ & 14 & 14 & 4 & 12 & 20 & $\mathbf{0}$ & 16 & 13 & 3 & 12 & 17 & 3 \\
\hline
\end{tabular}


Table 7: Correlations matrix for Europeanization sample

\begin{tabular}{|c|c|c|c|c|c|c|c|}
\hline & & $\begin{array}{c}\text { Cause v } \\
\text { Effect }\end{array}$ & $\begin{array}{l}\text { Concept v } \\
\text { Measure }\end{array}$ & $\begin{array}{c}\text { Complex v } \\
\text { Singular }\end{array}$ & $\begin{array}{l}\text { Parsimony v } \\
\text { Rich }\end{array}$ & $\begin{array}{c}\text { Time quant v } \\
\text { qual }\end{array}$ & $\begin{array}{c}\text { Mechan v } \\
\text { variabel }\end{array}$ \\
\hline \multirow[t]{3}{*}{ Cause v Effect } & Pearson Correlation & 1 & .070 & -.090 & .051 & -.135 & .252 \\
\hline & Sig. (2-tailed) & & .705 & .625 & .783 & .462 & .164 \\
\hline & $\mathrm{N}$ & 32 & 32 & 32 & 32 & 32 & 32 \\
\hline \multirow[t]{3}{*}{ Concept v Measure } & Pearson Correlation & .070 & 1 & $.362\left(^{*}\right)$ & $-.383\left(^{*}\right)$ & .203 & $.412\left(^{*}\right)$ \\
\hline & Sig. (2-tailed) & .705 & & .042 & .030 & .265 & .019 \\
\hline & $\mathrm{N}$ & 32 & 32 & 32 & 32 & 32 & 32 \\
\hline \multirow[t]{3}{*}{ Complex v Singular } & Pearson Correlation & -.090 & $.362\left(^{*}\right)$ & 1 & .009 & -.040 & .294 \\
\hline & Sig. (2-tailed) & .625 & .042 & & .961 & .826 & .102 \\
\hline & $\mathrm{N}$ & 32 & 32 & 32 & 32 & 32 & 32 \\
\hline \multirow[t]{3}{*}{ Parsimony v Rich } & Pearson Correlation & .051 & $-.383\left(^{*}\right)$ & .009 & 1 & -.298 & -.185 \\
\hline & Sig. (2-tailed) & .783 & .030 & .961 & & .098 & .311 \\
\hline & $\mathrm{N}$ & 32 & 32 & 32 & 32 & 32 & 32 \\
\hline \multirow[t]{3}{*}{ Time quant $v$ qual } & Pearson Correlation & -.135 & .203 & -.040 & -.298 & 1 & .006 \\
\hline & Sig. (2-tailed) & .462 & .265 & .826 & .098 & & .975 \\
\hline & $\mathrm{N}$ & 32 & 32 & 32 & 32 & 32 & 32 \\
\hline \multirow[t]{3}{*}{ Mechan v var } & Pearson Correlation & .252 & $.412\left(^{*}\right)$ & .294 & -.185 & .006 & 1 \\
\hline & Sig. (2-tailed) & .164 & .019 & .102 & .311 & .975 & \\
\hline & N & 32 & 32 & 32 & 32 & 32 & 32 \\
\hline
\end{tabular}

${ }^{*}$ Correlation is significant at the 0.05 level (2-tailed).

Source: Authors' calculations on SPSS

Table 8: Correlations matrix for Control Group sample

\begin{tabular}{|c|c|c|c|c|c|c|c|}
\hline & & $\begin{array}{c}\text { Cause v } \\
\text { Effect }\end{array}$ & $\begin{array}{l}\text { Concept v } \\
\text { Measure }\end{array}$ & $\begin{array}{c}\text { Complex v } \\
\text { Singular }\end{array}$ & $\begin{array}{c}\text { Parsimony v } \\
\text { Rich }\end{array}$ & $\begin{array}{c}\text { Time quant } v \\
\text { qual }\end{array}$ & $\begin{array}{c}\text { Mechanism v } \\
\text { variable }\end{array}$ \\
\hline \multirow[t]{3}{*}{ Cause v Effect } & Pearson Correlation & 1 & -.258 & $.410\left(^{*}\right)$ & .000 & -.128 & $-.493(* *)$ \\
\hline & Sig. (2-tailed) & & .154 & .020 & 1.000 & .485 & .004 \\
\hline & $\mathrm{N}$ & 32 & 32 & 32 & 32 & 32 & 32 \\
\hline \multirow[t]{3}{*}{ Concept v Measure } & Pearson Correlation & -258 & 1 & $-.370\left(^{*}\right)$ & .298 & .083 & .202 \\
\hline & Sig. (2-tailed) & .154 & & .037 & .097 & .653 & .267 \\
\hline & $\mathrm{N}$ & 32 & 32 & 32 & 32 & 32 & 32 \\
\hline \multirow[t]{3}{*}{ Complex v Singular } & Pearson Correlation & $.410\left(^{*}\right)$ & $-.370\left(^{*}\right)$ & 1 & .024 & -.074 & -.060 \\
\hline & Sig. (2-tailed) & .020 & .037 & & .898 & .686 & .746 \\
\hline & $\mathrm{N}$ & 32 & 32 & 32 & 32 & 32 & 32 \\
\hline \multirow[t]{3}{*}{ Parsimony v Rich } & Pearson Correlation & .000 & .298 & .024 & 1 & -.086 & .271 \\
\hline & Sig. (2-tailed) & 1.000 & .097 & .898 & & .639 & .133 \\
\hline & $\mathrm{N}$ & 32 & 32 & 32 & 32 & 32 & 32 \\
\hline \multirow[t]{3}{*}{ Time quant $v$ qual } & Pearson Correlation & -.128 & .083 & -.074 & -.086 & 1 & -.050 \\
\hline & Sig. (2-tailed) & .485 & .653 & .686 & .639 & & .785 \\
\hline & $\mathrm{N}$ & 32 & 32 & 32 & 32 & 32 & 32 \\
\hline \multirow[t]{3}{*}{ Mechan v var } & Pearson Correlation & $\left.-.4933^{(* *}\right)$ & .202 & -.060 & .271 & -.050 & 1 \\
\hline & Sig. (2-tailed) & .004 & .267 & .746 & .133 & .785 & \\
\hline & $\mathrm{N}$ & 32 & 32 & 32 & 32 & 32 & 32 \\
\hline
\end{tabular}

${ }^{*}$ Correlation is significant at the 0.05 level (2-tailed).

** Correlation is significant at the 0.01 level (2-tailed).

Source: Authors' calculations on SPSS 
Table 9: Scorecard of the Europeanization sample

\begin{tabular}{|c|c|c|c|c|c|c|c|c|c|c|c|c|c|c|c|c|c|c|c|c|c|c|}
\hline \multirow[b]{3}{*}{ ID } & \multirow[b]{3}{*}{ AUTHOR (Year) } & \multicolumn{21}{|c|}{ TRADE-OFFS IN CAUSAL ANALYSIS } \\
\hline & & \multicolumn{3}{|c|}{1} & \multicolumn{3}{|c|}{2} & \multicolumn{3}{|c|}{3} & \multicolumn{3}{|c|}{4} & \multicolumn{3}{|c|}{5} & \multicolumn{3}{|c|}{6} & \multicolumn{3}{|c|}{7} \\
\hline & & 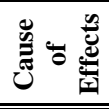 & 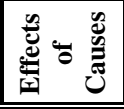 & $\overleftrightarrow{\mathrm{z}}$ & - & 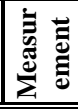 & $\overleftrightarrow{\mathrm{z}}$ & 容言 & ب̂. & $\vec{z}$ & 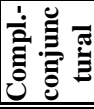 & 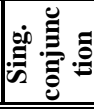 & $\vec{z}$ & 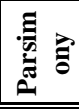 & 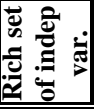 & $\mathbb{z}$ & 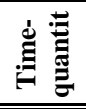 & 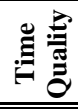 & $\mathbb{z}$ & 考 & 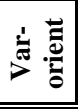 & $\mathbb{z}$ \\
\hline 1 & Ágh 2002 & $\mathbf{0}$ & 1 & $\mathbf{0}$ & $\mathbf{0}$ & 1 & $\mathbf{0}$ & 1 & $\overline{0}$ & 0 & $\overline{0}$ & 1 & (0) & $\overline{0}$ & 1 & $\overline{0}$ & 1 & $\overline{\mathbf{0}}$ & (0) & $\overline{0}$ & 1 & $\overline{0}$ \\
\hline 2 & Andersen 2002 & $\mathbf{0}$ & 1 & $\mathbf{0}$ & $\mathbf{0}$ & 1 & $\mathbf{0}$ & 1 & $\mathbf{0}$ & $\mathbf{0}$ & $\mathbf{0}$ & 1 & $\mathbf{0}$ & $\mathbf{0}$ & 1 & $\mathbf{0}$ & 1 & $\mathbf{0}$ & $\mathbf{0}$ & $\mathbf{0}$ & 1 & $\mathbf{0}$ \\
\hline 3 & Anderson JJ 2002 & $\mathbf{0}$ & 1 & $\mathbf{0}$ & $\mathbf{0}$ & 1 & $\mathbf{0}$ & 1 & $\mathbf{0}$ & $\mathbf{0}$ & $\mathbf{0}$ & 1 & $\mathbf{0}$ & $\mathbf{0}$ & 1 & $\mathbf{0}$ & $\mathbf{0}$ & 1 & $\mathbf{0}$ & $\mathbf{0}$ & 1 & $\mathbf{0}$ \\
\hline 4 & Benz \& Eberlein 1999 & 1 & $\mathbf{0}$ & $\mathbf{0}$ & $\mathbf{0}$ & 1 & $\mathbf{0}$ & 1 & $\mathbf{0}$ & $\mathbf{0}$ & 1 & $\mathbf{0}$ & $\mathbf{0}$ & $\mathbf{0}$ & 1 & $\mathbf{0}$ & 1 & $\mathbf{0}$ & $\mathbf{0}$ & $\mathbf{0}$ & 1 & $\mathbf{0}$ \\
\hline 5 & Beyers \& Trondal 2004 & 1 & $\mathbf{0}$ & $\mathbf{0}$ & $\mathbf{0}$ & 1 & $\mathbf{0}$ & $\mathbf{0}$ & 1 & $\mathbf{0}$ & $\mathbf{0}$ & 1 & $\mathbf{0}$ & 1 & $\mathbf{0}$ & $\mathbf{0}$ & $\mathbf{0}$ & $\mathbf{0}$ & -1 & 1 & $\mathbf{0}$ & $\mathbf{0}$ \\
\hline 6 & Börzel 1999 & $\mathbf{0}$ & 1 & $\mathbf{0}$ & 1 & $\mathbf{0}$ & $\mathbf{0}$ & 1 & $\mathbf{0}$ & $\mathbf{0}$ & 1 & $\mathbf{0}$ & $\mathbf{0}$ & $\mathbf{0}$ & 1 & $\mathbf{0}$ & 1 & $\mathbf{0}$ & $\mathbf{0}$ & 1 & $\mathbf{0}$ & $\mathbf{0}$ \\
\hline 7 & Börzel 2002 & 1 & $\mathbf{0}$ & $\mathbf{0}$ & 1 & $\mathbf{0}$ & $\mathbf{0}$ & 1 & $\mathbf{0}$ & $\mathbf{0}$ & $\mathbf{0}$ & $\mathbf{0}$ & -1 & $\mathbf{0}$ & $\mathbf{0}$ & -1 & 1 & $\mathbf{0}$ & $\mathbf{0}$ & 1 & $\mathbf{0}$ & $\mathbf{0}$ \\
\hline 8 & Bursens 2002 & 1 & $\mathbf{0}$ & $\mathbf{0}$ & $\mathbf{0}$ & 1 & $\mathbf{0}$ & 1 & $\mathbf{0}$ & $\mathbf{0}$ & 1 & $\mathbf{0}$ & $\mathbf{0}$ & $\mathbf{0}$ & 1 & $\mathbf{0}$ & 1 & $\mathbf{0}$ & $\mathbf{0}$ & 1 & $\mathbf{0}$ & $\mathbf{0}$ \\
\hline 9 & Cole 2001 & 1 & $\mathbf{0}$ & $\mathbf{0}$ & $\mathbf{0}$ & 1 & $\mathbf{0}$ & 1 & $\mathbf{0}$ & $\mathbf{0}$ & $\mathbf{0}$ & 1 & $\mathbf{0}$ & 1 & $\mathbf{0}$ & $\mathbf{0}$ & $\mathbf{0}$ & 1 & $\mathbf{0}$ & 1 & $\mathbf{0}$ & $\mathbf{0}$ \\
\hline 10 & Cole \& Drake 2000 & $\mathbf{0}$ & 1 & $\mathbf{0}$ & 1 & $\mathbf{0}$ & $\mathbf{0}$ & $\mathbf{0}$ & 1 & $\mathbf{0}$ & 1 & $\mathbf{0}$ & $\mathbf{0}$ & $\mathbf{0}$ & 1 & $\mathbf{0}$ & $\mathbf{0}$ & 1 & $\mathbf{0}$ & $\mathbf{0}$ & 1 & $\mathbf{0}$ \\
\hline 11 & Dimitrova 2002 & $\mathbf{0}$ & 1 & $\mathbf{0}$ & $\mathbf{0}$ & 1 & $\mathbf{0}$ & 1 & $\mathbf{0}$ & $\mathbf{0}$ & $\mathbf{0}$ & 1 & $\mathbf{0}$ & $\mathbf{0}$ & 1 & $\mathbf{0}$ & $\mathbf{0}$ & $\mathbf{0}$ & -1 & $\mathbf{0}$ & 1 & $\mathbf{0}$ \\
\hline 12 & Dyson 2000 & $\mathbf{0}$ & 1 & $\mathbf{0}$ & $\mathbf{0}$ & 1 & $\mathbf{0}$ & 1 & $\mathbf{0}$ & $\mathbf{0}$ & $\mathbf{0}$ & $\mathbf{0}$ & -1 & $\mathbf{0}$ & $\mathbf{0}$ & -1 & $\mathbf{0}$ & 1 & $\mathbf{0}$ & 1 & $\mathbf{0}$ & $\mathbf{0}$ \\
\hline 13 & Eyre \& Lodge 2000 & $\mathbf{0}$ & 1 & $\mathbf{0}$ & $\mathbf{0}$ & 1 & $\mathbf{0}$ & 1 & $\mathbf{0}$ & $\mathbf{0}$ & 1 & $\mathbf{0}$ & $\mathbf{0}$ & 1 & $\mathbf{0}$ & $\mathbf{0}$ & $\mathbf{0}$ & $\mathbf{0}$ & -1 & 1 & $\mathbf{0}$ & $\mathbf{0}$ \\
\hline 14 & Falkner & $\mathbf{0}$ & 1 & $\mathbf{0}$ & $\mathbf{0}$ & 1 & $\mathbf{0}$ & 1 & $\mathbf{0}$ & $\mathbf{0}$ & 1 & $\mathbf{0}$ & $\mathbf{0}$ & $\mathbf{0}$ & 1 & $\mathbf{0}$ & $\mathbf{0}$ & 1 & $\mathbf{0}$ & 1 & $\mathbf{0}$ & $\mathbf{0}$ \\
\hline 15 & Fischer; Nicolet; Sciarini 2002 & $\mathbf{0}$ & 1 & $\mathbf{0}$ & $\mathbf{0}$ & 1 & $\mathbf{0}$ & 1 & $\mathbf{0}$ & $\mathbf{0}$ & $\mathbf{0}$ & 1 & $\mathbf{0}$ & 1 & $\mathbf{0}$ & $\mathbf{0}$ & 1 & $\mathbf{0}$ & $\mathbf{0}$ & $\mathbf{0}$ & 1 & $\mathbf{0}$ \\
\hline 16 & Gilardi 2005 & 1 & $\mathbf{0}$ & $\mathbf{0}$ & $\mathbf{0}$ & 1 & $\mathbf{0}$ & $\mathbf{0}$ & $\mathbf{0}$ & -1 & $\mathbf{0}$ & 1 & $\mathbf{0}$ & 1 & $\mathbf{0}$ & $\mathbf{0}$ & $\mathbf{0}$ & 1 & $\mathbf{0}$ & 1 & $\mathbf{0}$ & $\mathbf{0}$ \\
\hline 17 & Grabbe 2001 & $\mathbf{0}$ & 1 & $\mathbf{0}$ & 1 & $\mathbf{0}$ & $\mathbf{0}$ & 1 & $\mathbf{0}$ & $\mathbf{0}$ & 1 & $\mathbf{0}$ & $\mathbf{0}$ & $\mathbf{0}$ & 1 & $\mathbf{0}$ & 1 & $\mathbf{0}$ & $\mathbf{0}$ & 1 & $\mathbf{0}$ & $\mathbf{0}$ \\
\hline 18 & Harmsen 1999 & 1 & $\mathbf{0}$ & $\mathbf{0}$ & $\mathbf{0}$ & 1 & $\mathbf{0}$ & 1 & $\mathbf{0}$ & $\mathbf{0}$ & $\mathbf{0}$ & $\mathbf{0}$ & -1 & 0 & 1 & $\mathbf{0}$ & 1 & $\mathbf{0}$ & $\mathbf{0}$ & $\mathbf{0}$ & 1 & $\mathbf{0}$ \\
\hline 19 & Knill \& Lehmkuhl 2002 & 1 & $\mathbf{0}$ & $\mathbf{0}$ & 1 & $\mathbf{0}$ & $\mathbf{0}$ & 1 & $\mathbf{0}$ & $\mathbf{0}$ & 1 & $\mathbf{0}$ & $\mathbf{0}$ & $\mathbf{0}$ & $\mathbf{0}$ & -1 & $\mathbf{0}$ & 1 & $\mathbf{0}$ & 1 & $\mathbf{0}$ & $\mathbf{0}$ \\
\hline 20 & Ladrech 2002 & 1 & $\mathbf{0}$ & $\mathbf{0}$ & 1 & $\mathbf{0}$ & $\mathbf{0}$ & $\mathbf{0}$ & $\mathbf{0}$ & -1 & 1 & $\mathbf{0}$ & $\mathbf{0}$ & $\mathbf{0}$ & 1 & $\mathbf{0}$ & $\mathbf{0}$ & 1 & $\mathbf{0}$ & 1 & $\mathbf{0}$ & $\mathbf{0}$ \\
\hline 21 & Lavenex 2001 & 1 & $\mathbf{0}$ & $\mathbf{0}$ & $\mathbf{0}$ & 1 & $\mathbf{0}$ & $\mathbf{0}$ & 1 & $\mathbf{0}$ & $\mathbf{0}$ & $\mathbf{0}$ & -1 & $\mathbf{0}$ & 1 & $\mathbf{0}$ & $\mathbf{0}$ & 1 & $\mathbf{0}$ & $\mathbf{0}$ & 1 & $\mathbf{0}$ \\
\hline 22 & Levi-Faur 2004 & $\mathbf{0}$ & 1 & $\mathbf{0}$ & $\mathbf{0}$ & 1 & $\mathbf{0}$ & $\mathbf{0}$ & $\mathbf{0}$ & -1 & $\mathbf{0}$ & 1 & $\mathbf{0}$ & 1 & $\mathbf{0}$ & $\mathbf{0}$ & 1 & $\mathbf{0}$ & $\mathbf{0}$ & $\mathbf{0}$ & 1 & $\mathbf{0}$ \\
\hline 23 & Lippert, Umbach, Wessels 2001 & 1 & $\mathbf{0}$ & $\mathbf{0}$ & 1 & $\mathbf{0}$ & $\mathbf{0}$ & 1 & $\mathbf{0}$ & $\mathbf{0}$ & 1 & $\mathbf{0}$ & $\mathbf{0}$ & 1 & $\mathbf{0}$ & $\mathbf{0}$ & $\mathbf{0}$ & 1 & $\mathbf{0}$ & 1 & $\mathbf{0}$ & $\mathbf{0}$ \\
\hline 24 & Lodge 2000 & $\mathbf{0}$ & 1 & $\mathbf{0}$ & 1 & $\mathbf{0}$ & $\mathbf{0}$ & $\mathbf{0}$ & $\mathbf{0}$ & -1 & 1 & $\mathbf{0}$ & $\mathbf{0}$ & $\mathbf{0}$ & $\mathbf{0}$ & -1 & 1 & $\mathbf{0}$ & $\mathbf{0}$ & 1 & $\mathbf{0}$ & $\mathbf{0}$ \\
\hline 25 & Marcussen, Risse et al. 1999 & 1 & $\mathbf{0}$ & $\mathbf{0}$ & $\mathbf{0}$ & 1 & $\mathbf{0}$ & $\mathbf{0}$ & 1 & $\mathbf{0}$ & $\mathbf{0}$ & 1 & $\mathbf{0}$ & 1 & $\mathbf{0}$ & $\mathbf{0}$ & $\mathbf{0}$ & 1 & $\mathbf{0}$ & $\mathbf{0}$ & 1 & $\mathbf{0}$ \\
\hline 26 & Radaelli 1997 & 1 & $\mathbf{0}$ & $\mathbf{0}$ & $\mathbf{0}$ & 1 & $\mathbf{0}$ & $\mathbf{0}$ & 1 & $\mathbf{0}$ & $\mathbf{0}$ & 1 & $\mathbf{0}$ & $\mathbf{0}$ & 1 & $\mathbf{0}$ & $\mathbf{0}$ & 1 & $\mathbf{0}$ & 1 & $\mathbf{0}$ & $\mathbf{0}$ \\
\hline 27 & Scharpf 1997 & $\mathbf{0}$ & 1 & $\mathbf{0}$ & $\mathbf{0}$ & 1 & $\mathbf{0}$ & $\mathbf{0}$ & $\mathbf{0}$ & -1 & 1 & $\mathbf{0}$ & $\mathbf{0}$ & $\mathbf{0}$ & 1 & $\mathbf{0}$ & 1 & $\mathbf{0}$ & $\mathbf{0}$ & 1 & $\mathbf{0}$ & $\mathbf{0}$ \\
\hline 28 & Schimmelfennig \& Sedelmeier 2004 & 1 & $\mathbf{0}$ & $\mathbf{0}$ & $\mathbf{0}$ & 1 & $\mathbf{0}$ & 1 & $\mathbf{0}$ & $\mathbf{0}$ & 1 & $\mathbf{0}$ & $\mathbf{0}$ & $\mathbf{0}$ & 1 & $\mathbf{0}$ & $\mathbf{0}$ & 1 & $\mathbf{0}$ & 1 & $\mathbf{0}$ & $\mathbf{0}$ \\
\hline 29 & Schmidt 2002 & 1 & $\mathbf{0}$ & $\mathbf{0}$ & 1 & $\mathbf{0}$ & $\mathbf{0}$ & 1 & $\mathbf{0}$ & $\mathbf{0}$ & 1 & $\mathbf{0}$ & $\mathbf{0}$ & $\mathbf{0}$ & 1 & $\mathbf{0}$ & $\mathbf{0}$ & 1 & $\mathbf{0}$ & 1 & $\mathbf{0}$ & $\mathbf{0}$ \\
\hline 30 & Semetko; De Vreese; Peter J 2000 & $\mathbf{0}$ & 1 & $\mathbf{0}$ & $\mathbf{0}$ & 1 & $\mathbf{0}$ & $\mathbf{1}$ & $\mathbf{0}$ & $\mathbf{0}$ & 1 & $\mathbf{0}$ & $\mathbf{0}$ & $\mathbf{0}$ & 1 & $\mathbf{0}$ & $\mathbf{0}$ & 1 & $\mathbf{0}$ & $\mathbf{0}$ & 1 & $\mathbf{0}$ \\
\hline 31 & Smith J 2001 & $\mathbf{0}$ & 1 & $\mathbf{0}$ & $\mathbf{0}$ & 1 & $\mathbf{0}$ & $\mathbf{1}$ & $\mathbf{0}$ & $\mathbf{0}$ & $\mathbf{0}$ & 1 & $\mathbf{0}$ & 1 & $\mathbf{0}$ & $\mathbf{0}$ & $\mathbf{0}$ & $\mathbf{0}$ & -1 & $\mathbf{0}$ & 1 & $\mathbf{0}$ \\
\hline 32 & Warleigh A 2001 & 1 & $\mathbf{0}$ & $\mathbf{0}$ & $\mathbf{0}$ & 1 & $\mathbf{0}$ & $\mathbf{0}$ & $\mathbf{0}$ & -1 & 1 & $\mathbf{0}$ & $\mathbf{0}$ & $\mathbf{0}$ & 1 & $\mathbf{0}$ & $\mathbf{0}$ & $\mathbf{0}$ & -1 & $\mathbf{0}$ & 1 & $\mathbf{0}$ \\
\hline & TOTAL OBSERVATIONS (N=32) & 16 & 16 & $\mathbf{0}$ & 9 & 23 & $\mathbf{0}$ & 21 & 5 & 6 & 16 & 12 & 4 & 9 & 19 & 4 & 12 & 15 & 5 & 18 & 14 & $\mathbf{0}$ \\
\hline
\end{tabular}


Table 10: Scorecard of the Control Group sample

\begin{tabular}{|c|c|c|c|c|c|c|c|c|c|c|c|c|c|c|c|c|c|c|c|}
\hline \multirow[b]{3}{*}{ ID } & \multirow[b]{3}{*}{ AUTHOR (Year) } & \multicolumn{18}{|c|}{ TRADE-OFFS IN CAUSAL ANALYSIS } \\
\hline & & \multicolumn{3}{|c|}{1} & \multicolumn{3}{|c|}{2} & \multicolumn{3}{|c|}{4} & \multicolumn{3}{|c|}{5} & \multicolumn{3}{|c|}{6} & \multicolumn{3}{|c|}{7} \\
\hline & & 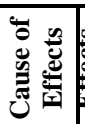 & & $\overleftrightarrow{\mathrm{z}}$ & 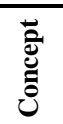 & 产 & $\overleftrightarrow{z}$ & 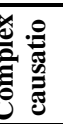 & 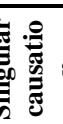 & $\widehat{z}$ & 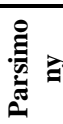 & 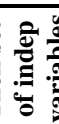 & $\widehat{z}$ & 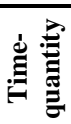 & 密 & 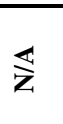 & $\bar{E}$ & 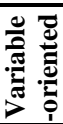 & $\widehat{z}$ \\
\hline 1 & Alter 1998 & $\overline{0}$ & 1 & $\mathbf{0}$ & $\mathbf{0}$ & 1 & $\mathbf{0}$ & 1 & $\overline{0}$ & $\mathbf{0}$ & $\overline{0}$ & 1 & $\overline{0}$ & 1 & $\mathbf{0}$ & $\mathbf{0}$ & 1 & $\mathbf{0}$ & $\mathbf{0}$ \\
\hline 2 & Anderson CJ 1998 & $\mathbf{0}$ & 1 & $\mathbf{0}$ & $\mathbf{0}$ & 1 & $\mathbf{0}$ & $\mathbf{0}$ & 1 & $\mathbf{0}$ & $\mathbf{0}$ & 1 & $\mathbf{0}$ & 1 & $\mathbf{0}$ & $\mathbf{0}$ & $\mathbf{0}$ & 1 & $\mathbf{0}$ \\
\hline 3 & Boyle 2000 & 1 & $\mathbf{0}$ & $\mathbf{0}$ & $\mathbf{0}$ & 1 & $\mathbf{0}$ & 1 & $\mathbf{0}$ & $\mathbf{0}$ & $\mathbf{0}$ & 1 & $\mathbf{0}$ & $\mathbf{0}$ & 1 & $\mathbf{0}$ & 1 & $\mathbf{0}$ & $\mathbf{0}$ \\
\hline 4 & \begin{tabular}{|l|} 
Carrubba 2001 \\
\end{tabular} & 1 & $\mathbf{0}$ & $\mathbf{0}$ & $\mathbf{0}$ & 1 & $\mathbf{0}$ & $\mathbf{0}$ & 1 & $\mathbf{0}$ & $\mathbf{0}$ & 1 & $\mathbf{0}$ & 1 & $\mathbf{0}$ & $\mathbf{0}$ & $\mathbf{0}$ & 1 & $\mathbf{0}$ \\
\hline 5 & \begin{tabular}{|l|} 
Cichowski 2000 \\
\end{tabular} & 1 & $\mathbf{0}$ & $\mathbf{0}$ & $\mathbf{0}$ & 1 & $\mathbf{0}$ & 1 & $\mathbf{0}$ & $\mathbf{0}$ & $\mathbf{0}$ & 1 & $\mathbf{0}$ & 1 & $\mathbf{0}$ & $\mathbf{0}$ & $\mathbf{0}$ & 1 & $\mathbf{0}$ \\
\hline 6 & Cole and Drake 2000 & $\mathbf{0}$ & 1 & $\mathbf{0}$ & 1 & $\mathbf{0}$ & $\mathbf{0}$ & 1 & $\mathbf{0}$ & $\mathbf{0}$ & $\mathbf{0}$ & 1 & $\mathbf{0}$ & $\mathbf{0}$ & 1 & $\mathbf{0}$ & $\mathbf{0}$ & 1 & $\mathbf{0}$ \\
\hline 7 & Friis and Murphy 1999 & $\mathbf{0}$ & 1 & $\mathbf{0}$ & $\mathbf{0}$ & 1 & $\mathbf{0}$ & 1 & $\mathbf{0}$ & $\mathbf{0}$ & $\mathbf{0}$ & 1 & $\mathbf{0}$ & $\mathbf{0}$ & 1 & $\mathbf{0}$ & 1 & $\mathbf{0}$ & $\mathbf{0}$ \\
\hline 8 & Gabel 1998 & 1 & $\mathbf{0}$ & 0 & $\mathbf{0}$ & 1 & 0 & $\mathbf{0}$ & 1 & $\mathbf{0}$ & $\mathbf{0}$ & 1 & $\mathbf{0}$ & 1 & $\mathbf{0}$ & $\mathbf{0}$ & $\mathbf{0}$ & 1 & $\mathbf{0}$ \\
\hline 9 & Garrett, Kelemen, Schulz 1998 & 1 & $\mathbf{0}$ & $\mathbf{0}$ & 1 & $\mathbf{0}$ & $\mathbf{0}$ & $\mathbf{0}$ & 1 & $\mathbf{0}$ & 1 & $\mathbf{0}$ & $\mathbf{0}$ & $\mathbf{0}$ & 1 & $\mathbf{0}$ & 1 & $\mathbf{0}$ & $\mathbf{0}$ \\
\hline 10 & \begin{tabular}{|l} 
Haas PM 1998 \\
\end{tabular} & 1 & $\mathbf{0}$ & $\mathbf{0}$ & $\mathbf{0}$ & 1 & $\mathbf{0}$ & 1 & $\mathbf{0}$ & $\mathbf{0}$ & $\mathbf{0}$ & 1 & $\mathbf{0}$ & 1 & $\mathbf{0}$ & $\mathbf{0}$ & $\mathbf{0}$ & 1 & $\mathbf{0}$ \\
\hline 11 & \begin{tabular}{|l|} 
Hix 1999 \\
\end{tabular} & 1 & $\mathbf{0}$ & $\mathbf{0}$ & $\mathbf{0}$ & 1 & $\mathbf{0}$ & 1 & $\mathbf{0}$ & $\mathbf{0}$ & $\mathbf{0}$ & 1 & $\mathbf{0}$ & 1 & $\mathbf{0}$ & $\mathbf{0}$ & $\mathbf{0}$ & 1 & $\mathbf{0}$ \\
\hline 12 & Hodson and Maher 2001 & $\mathbf{0}$ & $\mathbf{1}$ & $\mathbf{0}$ & 1 & $\mathbf{0}$ & $\mathbf{0}$ & $\mathbf{0}$ & 1 & $\mathbf{0}$ & 1 & $\mathbf{0}$ & $\mathbf{0}$ & 1 & $\mathbf{0}$ & $\mathbf{0}$ & 1 & $\mathbf{0}$ & $\mathbf{0}$ \\
\hline 13 & \begin{tabular}{|l} 
Huysmans 2000 \\
\end{tabular} & $\mathbf{0}$ & $\mathbf{1}$ & $\mathbf{0}$ & $\mathbf{0}$ & 1 & $\mathbf{0}$ & 1 & $\mathbf{0}$ & $\mathbf{0}$ & 1 & $\mathbf{0}$ & $\mathbf{0}$ & 1 & $\mathbf{0}$ & $\mathbf{0}$ & 1 & $\mathbf{0}$ & $\mathbf{0}$ \\
\hline 14 & Keating 1997 & $\mathbf{0}$ & 1 & $\mathbf{0}$ & $\mathbf{0}$ & 1 & $\mathbf{0}$ & $\mathbf{0}$ & $\mathbf{0}$ & -1 & 0 & 1 & $\mathbf{0}$ & $\mathbf{0}$ & 1 & $\mathbf{0}$ & 0 & 1 & $\mathbf{0}$ \\
\hline 15 & Leitner 1997 & 1 & $\mathbf{0}$ & $\mathbf{0}$ & $\mathbf{0}$ & 1 & $\mathbf{0}$ & 1 & $\mathbf{0}$ & $\mathbf{0}$ & 0 & 1 & $\mathbf{0}$ & $\mathbf{0}$ & 1 & $\mathbf{0}$ & 0 & 1 & $\mathbf{0}$ \\
\hline 16 & Mastenbroek 2003 & $\mathbf{0}$ & 1 & $\mathbf{0}$ & $\mathbf{0}$ & 1 & $\mathbf{0}$ & $\mathbf{0}$ & 1 & $\mathbf{0}$ & $\mathbf{0}$ & 1 & $\mathbf{0}$ & $\mathbf{0}$ & 1 & $\mathbf{0}$ & $\mathbf{0}$ & 1 & $\mathbf{0}$ \\
\hline 17 & McLaren LM 2002 & 1 & $\mathbf{0}$ & $\mathbf{0}$ & $\mathbf{0}$ & 1 & $\mathbf{0}$ & $\mathbf{0}$ & 1 & $\mathbf{0}$ & $\mathbf{0}$ & 1 & $\mathbf{0}$ & $\mathbf{0}$ & $\mathbf{0}$ & -1 & $\mathbf{0}$ & 1 & $\mathbf{0}$ \\
\hline 18 & Meyer C 1999 & 1 & $\mathbf{0}$ & $\mathbf{0}$ & $\mathbf{0}$ & 1 & $\mathbf{0}$ & $\mathbf{0}$ & 1 & $\mathbf{0}$ & 1 & $\mathbf{0}$ & $\mathbf{0}$ & 1 & $\mathbf{0}$ & $\mathbf{0}$ & $\mathbf{0}$ & 1 & $\mathbf{0}$ \\
\hline 19 & Paarlberg 1997 & 1 & $\mathbf{0}$ & $\mathbf{0}$ & $\mathbf{0}$ & 1 & $\mathbf{0}$ & 1 & $\mathbf{0}$ & $\mathbf{0}$ & 1 & $\mathbf{0}$ & $\mathbf{0}$ & $\mathbf{0}$ & 1 & $\mathbf{0}$ & $\mathbf{0}$ & 1 & $\mathbf{0}$ \\
\hline 20 & Pahre 1997 & $\mathbf{0}$ & 1 & $\mathbf{0}$ & $\mathbf{0}$ & 1 & $\mathbf{0}$ & $\mathbf{0}$ & 1 & $\mathbf{0}$ & $\mathbf{0}$ & 1 & $\mathbf{0}$ & 1 & $\mathbf{0}$ & $\mathbf{0}$ & 1 & $\mathbf{0}$ & $\mathbf{0}$ \\
\hline 21 & Pappi and Henning 1999 & 1 & $\mathbf{0}$ & $\mathbf{0}$ & $\mathbf{0}$ & 1 & $\mathbf{0}$ & $\mathbf{0}$ & 1 & $\mathbf{0}$ & $\mathbf{0}$ & 1 & $\mathbf{0}$ & $\mathbf{0}$ & $\mathbf{0}$ & -1 & $\mathbf{0}$ & 1 & $\mathbf{0}$ \\
\hline 22 & \begin{tabular}{|l|} 
Risse, Engelmann-Martin, et al 1999 \\
\end{tabular} & $\mathbf{0}$ & 1 & $\mathbf{0}$ & $\mathbf{0}$ & 1 & $\mathbf{0}$ & 1 & $\mathbf{0}$ & $\mathbf{0}$ & 1 & $\mathbf{0}$ & $\mathbf{0}$ & $\mathbf{0}$ & 1 & $\mathbf{0}$ & $\mathbf{0}$ & 1 & $\mathbf{0}$ \\
\hline 23 & Schimmelfennig 2000 & 1 & $\mathbf{0}$ & $\mathbf{0}$ & 1 & $\mathbf{0}$ & $\mathbf{0}$ & 1 & $\mathbf{0}$ & $\mathbf{0}$ & 1 & $\mathbf{0}$ & $\mathbf{0}$ & $\mathbf{0}$ & 1 & $\mathbf{0}$ & 1 & $\mathbf{0}$ & $\mathbf{0}$ \\
\hline 24 & Selck 2004 & $\mathbf{0}$ & 1 & $\mathbf{0}$ & 1 & $\mathbf{0}$ & $\mathbf{0}$ & $\mathbf{0}$ & $\mathbf{0}$ & -1 & $\mathbf{0}$ & 1 & $\mathbf{0}$ & 1 & $\mathbf{0}$ & $\mathbf{0}$ & $\mathbf{0}$ & 1 & $\mathbf{0}$ \\
\hline 25 & Selck and Steunenberg 2004 & $\mathbf{0}$ & 1 & $\mathbf{0}$ & $\mathbf{0}$ & 1 & $\mathbf{0}$ & $\mathbf{0}$ & 1 & $\mathbf{0}$ & 1 & $\mathbf{0}$ & $\mathbf{0}$ & $\mathbf{0}$ & $\mathbf{0}$ & -1 & 1 & $\mathbf{0}$ & $\mathbf{0}$ \\
\hline 26 & Smith A. 2002 & 1 & $\mathbf{0}$ & $\mathbf{0}$ & $\mathbf{0}$ & 1 & $\mathbf{0}$ & 1 & $\mathbf{0}$ & $\mathbf{0}$ & $\mathbf{0}$ & 1 & $\mathbf{0}$ & $\mathbf{0}$ & 1 & $\mathbf{0}$ & $\mathbf{0}$ & $\mathbf{0}$ & -1 \\
\hline 27 & Smith ME 2000 & $\mathbf{0}$ & 1 & $\mathbf{0}$ & 1 & $\mathbf{0}$ & $\mathbf{0}$ & $\mathbf{0}$ & $\mathbf{0}$ & -1 & 1 & $\mathbf{0}$ & $\mathbf{0}$ & $\mathbf{0}$ & 1 & $\mathbf{0}$ & 1 & $\mathbf{0}$ & $\mathbf{0}$ \\
\hline 28 & Spanou 1998 & $\mathbf{0}$ & $\mathbf{1}$ & $\mathbf{0}$ & $\mathbf{0}$ & 1 & $\mathbf{0}$ & $\mathbf{0}$ & 1 & $\mathbf{0}$ & 1 & $\mathbf{0}$ & $\mathbf{0}$ & 1 & $\mathbf{0}$ & $\mathbf{0}$ & 1 & $\mathbf{0}$ & $\mathbf{0}$ \\
\hline 29 & Taggart 1998 & 1 & $\mathbf{0}$ & $\mathbf{0}$ & $\mathbf{0}$ & 1 & $\mathbf{0}$ & $\mathbf{0}$ & 1 & $\mathbf{0}$ & $\mathbf{0}$ & 1 & $\mathbf{0}$ & 1 & $\mathbf{0}$ & $\mathbf{0}$ & $\mathbf{0}$ & $\mathbf{0}$ & -1 \\
\hline 30 & Tallberg 2002 & $\mathbf{0}$ & $\mathbf{0}$ & -1 & 1 & $\mathbf{0}$ & $\mathbf{0}$ & $\mathbf{0}$ & $\mathbf{0}$ & -1 & $\mathbf{0}$ & 1 & $\mathbf{0}$ & 1 & $\mathbf{0}$ & $\mathbf{0}$ & 1 & $\mathbf{0}$ & $\mathbf{0}$ \\
\hline 31 & Verdun 1999 & 1 & $\mathbf{0}$ & 0 & $\mathbf{1}$ & $\mathbf{0}$ & $\mathbf{0}$ & $\mathbf{0}$ & 1 & $\mathbf{0}$ & 1 & $\mathbf{0}$ & $\mathbf{0}$ & 1 & $\mathbf{0}$ & $\mathbf{0}$ & $\mathbf{0}$ & $\mathbf{0}$ & -1 \\
\hline 32 & Vogel 2003 & 1 & $\mathbf{0}$ & $\mathbf{0}$ & $\mathbf{0}$ & 1 & $\mathbf{0}$ & 1 & $\mathbf{0}$ & $\mathbf{0}$ & 1 & $\mathbf{0}$ & $\mathbf{0}$ & $\mathbf{0}$ & 1 & $\mathbf{0}$ & $\mathbf{0}$ & 1 & $\mathbf{0}$ \\
\hline & TOTAL OBSERVATIONS ( $\mathrm{N}=32)$ & 17 & 14 & 1 & 8 & 24 & $\mathbf{0}$ & 14 & 14 & 4 & 12 & 20 & $\mathbf{0}$ & 16 & 13 & 3 & 12 & 17 & 3 \\
\hline
\end{tabular}


